\title{
Santidade feminina no Rio de Janeiro setecentista: fragmentos da vida e da experiência religiosa de Jacinta de São José (1715-1768)
}

Feminine sanctity in 1700s Rio de Janeiro: fragments of the life and religious experience of Jacinta de São José (1715-1768)

William de Souza Martins*

Resumo: $\mathrm{O}$ artigo pretende examinar a experiência religiosa da beata Jacinta de São José, focalizando três aspectos principais: as relaçóes que manteve com diversos membros de ordens religiosas estabelecidas no Rio de Janeiro; os antecedentes familiares; e as relaçóes entre os escritos de vida de Jacinta e a literatura mística do século XVI.

Palavras-chave: Jacinta de São José, Jacinta Rodrigues Aires, beatas do século XVIII, História.

Abstract: The article intends to analyze the religious experience of beata Maria de São José, focusing on three main aspects: the relationship she had with several members of religious orders established in Rio de Janeiro; the family background; and relations between the writings of life of Jacinta and mystical literature of sixteenth century.

Keywords: Jacinta de São José, Jacinta Rodrigues Aires, beatas in the eighteenthcentury, History.

\section{Introdução}

No âmbito do projeto de pesquisa desenvolvido há pouco mais de dois anos, dedicado aos modelos de santidade feminina na América portuguesa no

\footnotetext{
* Doutor em História Social pela USP. Professor Adjunto do Instituto de História e do PPGHIS da UFRJ. O presente trabalho contou com o auxílio à Pesquisa APQ1, fornecido pela Faperj. Foi beneficiado também com a ajuda prestada pelas bolsistas de Iniciação Científica Helaine Nascimento e Mareana Barbosa na coleta de alguns dados. E-mail: <williamsmartins@uol.com.br>.
} 
século XVIII, seria impossível deixar de lado a análise da beata Jacinta de São José, considerada a fundadora do Convento de Santa Teresa do Rio de Janeiro. A historiografia, em anos recentes, vem se dedicando a esmiuçar as atividades da madre Jacinta, com destaque para os trabalhos da Professora Leila Mezan Algranti, sobretudo o último livro que dedicou à temática. Utilizando ampla documentação, constituída por relatos acerca das visóes e atividades religiosas de Jacinta, um processo inquisitorial e fontes internas do Convento de Santa Teresa, a autora fundamentou sua análise nos estudos de gênero e na crítica dos testemunhos hagiográficos. Estas últimas fontes, lavradas por autores masculinos, apresentaram Jacinta como um modelo de santidade a ser seguido. Ao lado disso, e apoiando-se em pesquisas efetuadas na biblioteca conventual, Algranti se ocupou também em identificar e discutir os livros que teriam sido importantes para a formação espiritual daquela beata mística. ${ }^{1}$ Outro estudo significativo foi realizado pela Professora Margareth de Almeida Gonçalves que, apoiando-se em uma análise comparativa dos relatos da religiosa Felipa da Trindade, de Goa, e dos de Jacinta de São José, procurou sublinhar a maior subjetividade das visóes de Jacinta, nas quais é nítida a influência da espiritualidade mística de Santa Teresa d'Ávila. ${ }^{2}$

Seguindo pistas lançadas pelos estudos mencionados, o presente trabalho pretende apresentar novas contribuições para o conhecimento da atuação daquela importante mística colonial. Em primeiro lugar, associando-a a outros agentes religiosos atuantes no Rio de Janeiro setecentista, cuja presença pode ser documentada antes e no decurso dos primeiros anos da atividade de Jacinta: os religiosos carmelitas descalços, os frades capuchinhos, o ermitáo de Nossa Senhora do Desterro, os irmãos da Ordem Terceira de São Francisco etc. Espera-se assim reconstituir melhor a complexidade das tensôes do campo religioso do período, ${ }^{3}$ marcado pela introdução de novas ordens religiosas e pelo controle maior das formas de vida semirreligiosa (representadas, acima de tudo, por beatas e ermitães) por parte das autoridades eclesiásticas, que tem sido alvo de análise em outros contextos. ${ }^{4}$ De modo admirável, Jacinta atraiu a atenção de vários segmentos do clero: religiosos carmelitas descalços, capuchinhos, jesuítas e padres diocesanos. Por outro lado, e seguindo um procedimento desenvolvido por Octavio Paz, ao tratar da trajetória de uma importante freira mexicana, buscar-se-á aprofundar as informaçôes acerca da família de Jacinta Rodrigues Aires, o nome de batismo

\footnotetext{
${ }^{1}$ L. M. ALGRANTI, Livros de devoção, atos de censura, p. 75-129.

${ }^{2}$ M. A. GONÇALVES, Império da fé, p. 131-166.

${ }^{3}$ P. BOURDIEU, Gênese e estrutura do campo religioso. In: A economia das trocas simbólicas, p. 27-98.

${ }_{4}^{4}$ M. L. KING, A mulher do Renascimento, p. 113-127. A. RUBIAL GARCIA, Profetisas y solitarios, p. 189-241. L. M. de SOUZA, Inferno Atlântico, p. 105-124.
} 
da mística fluminense. ${ }^{5}$ O propósito, aqui, não é efetuar uma biografia, mas sim cotejar as ditas informaçóes com os relatos acerca de Jacinta, esperando-se, com isso, identificar com mais precisão certas estratégias do discurso hagiográfico. Por fim, o terceiro objetivo deste trabalho é tentar aprofundar as análises de Leila Algranti e de Margareth Gonçalves quanto à influência da literatura mística sobre a vivência religiosa de Jacinta.

Para desenvolver os objetivos propostos acima, serão examinadas fontes de natureza variada, apenas em parte utilizada pelos estudos anteriores: a documentação do Arquivo Histórico Ultramarino referente ao Rio de Janeiro; obras de caráter institucional a respeito dos religiosos carmelitas descalços e dos capuchinhos; informaçóes biográficas de procedência variada; o processo do Santo Ofício de Lisboa que traz acusações e informaçóes relativas a Jacinta; a documentação de natureza hagiográfica; e algumas obras da mística quinhentista, principalmente o Livro da Vida de Santa Teresa d'Ávila, ou de Jesus, conforme a designação das fontes. De modo a permitir um maior aprofundamento das questóes propostas, a análise da trajetória religiosa de Jacinta enfocará principalmente a década de 1740, deixando-se de lado o conflito que travou mais tarde com o bispo do Rio de Janeiro, D. fr. Antônio do Desterro Malheiros. A documentação do Santo Ofício será analisada apenas em caráter pontual, pois a riqueza das informaçóes ali contidas justifica um tratamento à parte, que se espera realizar em breve. ${ }^{6}$

Duas fontes de caráter hagiográfico merecem um comentário específico: o relato acerca da fundação do Convento de Santa Teresa, publicado em 1835 por Balthazar da Silva Lisboa, doutor em leis pela Universidade de Coimbra e antigo provedor das Capelas e Resíduos do Rio de Janeiro, e a Vida de Jacinta, escrita pelo religioso carmelita descalço frei Nicolau de São José. Cem anos separam a publicação dos dois relatos. A diferença da condição dos autores, em um caso um letrado leigo e, no outro, um eclesiástico vinculado à Ordem preferida por Jacinta, constitui outra distinção a ser levada em conta. Não obstante, as narrativas que ambos produziram possuem mais semelhanças do que divergências, devido ao uso de uma fonte comum: um manuscrito acerca da vida de Jacinta, elaborado em 1819 por frei Joáo dos Santos, do Carmelo Descalço, conservado no Convento de Santa Teresa e nunca publicado, que compilava diversas informaçóes de confessores de Jacinta e de companheiras de clausura. Diante da impossibilidade de consultar tal manuscrito, os dois relatos impressos foram cuidadosamente cotejados e relacionados com outras fontes de natureza diversa.

\footnotetext{
5 O. PAZ, Sóror Juana Inés de la Cruz, p. 95-149.

${ }^{6}$ Foram atualizadas a ortografia e a pontuação das fontes. O uso original de maiúsculas foi preservado. Os títulos das obras também foram mantidos no original.
} 


\section{Jacinta e o campo religioso do Rio de Janeiro na primeira metade do Setecentos}

Todos os escritos de natureza hagiográfica que dão testemunho da vivência religiosa de Jacinta de São José confirmam o papel chave desempenhado pelo confessor e diretor espiritual fr. Manoel de Jesus. $\mathrm{O}$ frade carmelita descalço acompanhou de perto a mística entre os anos de 1744 e 1745, pouco depois de Jacinta haver se internado com a irmá Francisca na Chácara da Bica, nas proximidades da antiga capela de Nossa Senhora do Desterro. ${ }^{7}$ Assim, importa mapear mais de perto a atuação dos religiosos carmelitas seguidores da Reforma de Santa Teresa, ainda antes de entrarem em contato com Jacinta. Em 1714, após deixarem as missóes do rio São Francisco, os frades carmelitas descalços estiveram no Rio de Janeiro, com o objetivo de instalar uma fundação conventual. O marquês de Angeja, vice-rei do Brasil, enviou da Bahia uma carta para o bispo fluminense, D. Francisco de Sáo Jerônimo, solicitando o apoio deste para a causa dos missionários, de quem era muito devoto. Conforme se verifica na consulta do Conselho Ultramarino com data de 23 de março de 1716, o prelado do Rio de Janeiro cumpriu de fato o que prometera, pois "Ihes largara uma igreja cômoda, situada em um monte fora da povoação da cidade mas perto dela, sem vizinhanças, solitária com um ermitáo da invocação de Nossa Senhora do Desterro, a qual tem bens de rendimento e que com este se fará por anos o convento". Sublinhando o "grande exemplo e edificação" dos carmelitas descalços, o procurador da Coroa observou, não obstante, que "com tantos conventos e em terra pequena, acrescentar outro parecia muito convento, que se estes religiosos quisessem fundar em outra terra daquela capitania onde não há conventos, grande serviço fariam a Deus a Vossa Majestade". Três conselheiros ultramarinos posicionaram-se com um voto à parte, apoiando a intenção da fundação do convento dos carmelitas descalços, visto o aproveitamento espiritual que resultara da sua missão, e a isenção de custos para a Fazenda real, "pois se oferece a fazê-lo um ermitão constituindo-lhe renda para a sua sustentaçâo", desde que os religiosos não ultrapassassem o número de doze. O Conselho conformou-se com o parecer negativo do procurador da Coroa, como também a resolução régia. Assim, os frades Custódio de Jesus Maria, Manuel da Purificaçáo e Afonso de Jesus Maria, participantes da missão no Rio de Janeiro, voltaram a Salvador em 10 de setembro de 1716, "decepcionados por verem frustradas suas pretensôes".

\footnotetext{
7 B. da S. LISBOA, Annaes do Rio de Janeiro, t. VII, p. 399-445; Fr. N. de SÃO JOSÉ, Vida da serva de Deus madre Jacinta de São José, p. 8; Convento de Santa Teresa, p. 6.

${ }^{8}$ V. CALDERÓN, Biografia de um monumento, p. 84-87, 195-199; AHU, RJ, CA (Documentos catalogados por Eduardo de Castro e Almeida), no 3478-3481. Consulta do Conselho Ultramarino acerca da fundaçáo de um convento de religiosos carmelitas descalços de Santa Teresa que se pretendia estabelecer no Rio de Janeiro.
} 
O projeto, que acabou fracassado, dos carmelitas da Reforma de Santa Teresa, contava com um ponto de apoio decisivo na cidade do Rio de Janeiro: o ermitão Manoel Correa, que administrava a ermida de Nossa Senhora do Desterro da cidade no início do século XVIII. O templo fora fundado em 1624 por Antônio Gomes do Desterro, que

pela grande devoçáo que tinha para com este título, que também o tinha por apelido, lho dedicou, e a fazenda ou quinta em que o fundou quis que para sempre fosse da Senhora, e assim lhe fez doaçáo dela, e de outras fazendas, para que com os rendimentos dela se acudisse à fábrica da Casa da Senhora, e ornato de seu culto, como para sustento do Ermitão, que havia de ter cuidado da Casa e dos ornamentos, e serviço dela. ${ }^{9}$

O autor do Santuário mariano deixou uma descrição muito elogiosa do ermitão Manoel Correa: "homem honrado e virtuoso, e com muito propósito, a qual há muitos anos que assiste à Senhora, e com o grande amor com que a serve lhe tem aumentado muito a sua Casa e as suas rendas; porque tem um curral de gado nos campos de Irajá, partido de canas, escravos, e tudo em terra própria da Senhora". ${ }^{10}$ Todas as informaçóes apuradas sobre o ermitão Manoel Correa, seja na petição enviada pelos carmelitas descalços ao Conselho Ultramarino, seja nas obras dos memorialistas da cidade, podem ser confirmadas e ampliadas na documentação do próprio Conselho. No testamento datado de 12 de julho de 1716, Manoel Correa, nascido em Lamego e sem nenhum herdeiro forçado ao qual devesse deixar seus bens, fez as seguintes declaraçóes:

Declaro que comprei umas terras a que chamam o capão na freguesia de Irajá, nas quais fiz um curral de gado onde se acham 78 cabeças de gado, entre grandes e pequenas $=$ Item - declaro ter comprado dez moradas de casas nesta Cidade, fora as deste sítio, e aqui tenho 34 escravos, entre pequenos e grandes = Declaro que todos estes bens foram adquiridos por mim com muito trabalho e com tenção [sic] de mandar fazer neste sítio um convento dos Religiosos carmelitas descalços, para melhor se conservar e aumentar a devoção da dita senhora do Desterro, e assim quero e ordeno que se faça neste sítio o dito Convento com a invocaçáo de Nossa Senhora do Desterro, e a mesma Senhora do Desterro

\footnotetext{
Lisboa, 23 de março de 1716. Tem anexas cartas do vice-rei, bispo e Câmara. Disponível nos CDs do Projeto Resgate, consultados na Divisão de Manuscritos da Biblioteca Nacional do Rio de Janeiro.

${ }^{9}$ Fr. A. de SANTA MARIA, Santuário mariano, t. X, p. 18; A. MAURÍCIO, Igrejas históricas do Rio de Janeiro, p. 155.

${ }^{10}$ Fr. A. de SANTA MARIA, Santuário mariano, t. X, p. 18.
} 
instituo por minha universal herdeira de todos os bens declarados [...] e se entregará tudo aos ditos religiosos carmelitas descalços. ${ }^{11}$

Conforme pode ser apurado nas datas referentes à missão dos carmelitas descalços no Rio de Janeiro e à redação do testamento, o ermitão havia entrado em acordo com os frades em questão com vistas a beneficiá-los com os bens anexos a Nossa Senhora do Desterro, convertendo-os em patrimônio para um futuro convento da Ordem. Manoel Correa manifestou ainda a gratidão e a devoção que tinha pelos carmelitas da Reforma de Santa Teresa em duas cláusulas do testamento, ao determinar que o seu corpo fosse "amortalhado no hábito dos Religiosos Carmelitas descalços, de que se lhe dará esmola de dez mil réis [sic]"." Além disso, nomeou em primeiro lugar aos mesmos religiosos como testamenteiros, isto é, os responsáveis pelo cumprimento das disposiçóes testamentárias do ermitão. Havendo falecido em outubro de 1716, o ermitáo não conseguiu colocar em prática seus planos. Os representantes do bispado suspenderam a execuçáo do testamento, sob o pretexto de que o testador não podia dispor dos bens mencionados, na medida em que constituíam o patrimônio próprio da capela. De qualquer maneira, em 1716 os carmelitas descalços já haviam desistido do propósito de construir uma fundação conventual no Rio de Janeiro.

Depois de um hiato de mais de duas décadas, os religiosos carmelitas da Reforma de Santa Teresa voltaram a se estabelecer no Rio de Janeiro. Dessa vez, não para fundarem um convento, mas como acompanhantes do bispo D. fr. João da Cruz, ele próprio um membro da Ordem do Carmelo Descalço. Depois de escolhido pelo soberano, o novo bispo fluminense foi confirmado pelo papa Clemente XII e sagrado pelo cardeal patriarca de Lisboa em 05 de fevereiro de 1741. Em maio desse ano, tomou posse da diocese do Rio de Janeiro. Teve um episcopado atribulado, atraindo a oposição do ouvidor de Vila Rica, por ocasião de uma visita pastoral que realizara na regiāo das Minas. Segundo as Memórias do monsenhor Pizarro, tais conflitos foram determinantes para que D. fr. João da Cruz renunciasse ao bispado, em $1745 .{ }^{13}$ Além do bispo, as fontes referem mais um

\footnotetext{
${ }^{11}$ AHU, RJ, cx. 29, doc. 23 (cx. 28, d. 2931). Decreto do rei D. Joáo V concedendo licença ao procurador dos religiosos capuchos da província da Imaculada Conceição de Nossa Senhora do Rio de Janeiro para construir um seminário eclesiástico com os rendimentos da capela chamada de Nossa Senhora do Desterro, bem como de seus bens, com a declaraçáo de que se o referido seminário não for edificado ou extinto a mercê será revogada e os rendimentos da capela voltaráo para a Coroa. 7 de junho de 1735. Disponível em <www.cmd.unb.br>. Acesso em 29/10/2011.

${ }^{12}$ Idem.

${ }^{13} \mathrm{~J}$. de S. A. P. e ARAÚJO, Memórias históricas do Rio de Janeiro, v. 4, p. 161-166.
} 
religioso da dita Ordem que esteve em contato com Jacinta: o confessor e diretor espiritual padre Manoel de Jesus, companheiro e secretário do prelado fluminense. ${ }^{14}$

Como será visto em maiores detalhes um pouco mais adiante, entre $1736 \mathrm{e}$ 1742 Jacinta frequentava o templo de Nossa Senhora do Desterro, o antigo templo do ermitão Manoel Correa, ocupado naqueles últimos anos pelos religiosos capuchinhos italianos. A busca por sacramentos e exercícios de piedade naquele templo, e não na sua freguesia, devia-se, segundo as crônicas, à maior comodidade de deslocamento, em virtude de um acidente que a impedira de andar. As narrativas hagiográficas acerca da beata também assinalam que a ideia de adquirir a Chácara da Bica, situada de modo contíguo à igreja do Desterro, tomou corpo durante o período em que assistia regularmente às missas naquele templo. ${ }^{15} \mathrm{O}$ complexo plano de adquirir a Chácara e se retirar no interior da mesma, na companhia de sua irmá Francisca Rodrigues Aires e do meio-irmão José Gonçalves, concretizou-se apenas em 1742. Para tanto, foi decisiva a intermediação do seu tio materno, o capitão Manoel Pereira Ramos, que, apoiado pelo governador do Rio de Janeiro Gomes Freire de Andrade, conseguiu vencer resistências do proprietário da Chácara, cujas terras eram alugadas, e efetuar a transação da compra por dois contos e cem mil réis. A operação foi concluída em princípios de março de 1742 e, a 27 do mês em questão, Jacinta deixou a residência do padrasto e da mãe para se instalar na Chácara. ${ }^{16} \mathrm{~A}$ fixação na Chácara situada nas proximidades da capela do Desterro pode ser considerada o início da vida de recolhimento de Jacinta. $\mathrm{Na}$ ocasiáo, segundo relata um dos cronistas, deixou de lado o nome de batismo e passou a se chamar Jacinta de São José, enquanto a irmã Francisca Rodrigues Aires, que a acompanhara naquele retiro espiritual, se autodenominou de Francisca de Jesus Maria. ${ }^{17}$

Nessa etapa inicial, não há provas de que os carmelitas descalços tenham apoiado diretamente o projeto de Jacinta. Ainda que esta e a irmã Francisca tivessem antes mostrado inclinação para o ideal de vida religiosa, como será discutido adiante, não se pode aceitar sem críticas a crônica, segundo a qual, já naquele momento, "na obra humilde de Jacinta estava o dedo de Deus, que formara para ser a filha primogênita da Matriarca Santa Teresa de Jesus, na América do Sul" ${ }^{18} \mathrm{O}$ comentário de Balthazar da Silva Lisboa, ao se referir aos anos iniciais de Jacinta

\footnotetext{
${ }^{14}$ B. da S. LISBOA, Annaes, p. 398-399. A referência deste cronista a um religioso chamado "Manoel Francisco" deve tratar-se, provavelmente, de falha tipográfica, pois tal menção não aparece em nenhum momento nas demais fontes.

${ }^{15}$ B. da S. LISBOA, Annaes, p. 393; Fr. N. de SÃO JOSÉ, Vida da serva de Deus, p. 34.

${ }^{16}$ B. da S. LISBOA, Annaes, p. 394; Fr. N. de SÃO JOSÉ, Vida da serva de Deus, p. 35.

${ }^{17}$ B. da S. LISBOA, Annaes, p. 396.

${ }^{18}$ Fr. N. SÃO JOSÉ, Vida da serva de Deus, p. 39.
} 
e Francisca na Chácara da Bica, apresenta problemas análogos: "ali permaneceram aquelas primitivas flores do Carmelo brasílico com grande edificação, privadas voluntariamente de toda a comunicaçáo com as pessoas do século". ${ }^{19}$ Afastando-se, assim, da narrativa hagiográfica que, de uma maneira teleológica, interpreta todos os detalhes da vida de santidade sob a ótica da predestinação, parece adequado restituir alguma indefinição aos planos de Jacinta. ${ }^{20} \mathrm{O}$ modo de vida de recolhimento que seguia na Chácara da Bica assemelhava-se a muitos beatérios femininos que existiam na época colonial, em que mulheres, quase sempre de condição social mais elevada, ligadas às ordens terceiras de São Francisco ou do Carmo, e que frequentemente possuíam relaçóes de parentesco entre si, procuravam atingir um plano maior de perfeição religiosa. ${ }^{21}$ Todos os elementos descritos estavam presentes na Chácara da Bica.

Assim, parece mais provável que, em um primeiro momento, Jacinta não tivesse ainda a intenção de fundar na Chácara da Bica um convento da Reforma de Santa Teresa. É mais certo que essa ideia tenha amadurecido no triênio de 1743 a 1745, quando esteve em contato mais próximo com os religiosos carmelitas descalços, ou, ainda, mais tarde. Além da intensa atividade de acompanhamento espiritual, os religiosos da Reforma de Santa Teresa apoiaram a iniciativa de Jacinta de erguer, na Chácara da Bica, uma capela para abrigar uma imagem do Menino Deus que havia trazido consigo. Em acréscimo à finalidade devocional, as crônicas alegam razóes de comodidade para a construçáo de uma capela dentro da Chácara, poupando a Jacinta e a Francisca o esforço de saírem continuamente para a igreja do Desterro, em busca de serviços religiosos. ${ }^{22}$ A capela foi benzida em 31 de dezembro de 1743, festa de Sáo Silvestre, e no dia seguinte, dedicado à Circuncisáo do Senhor, celebrou nela a primeira missa o confessor de Jacinta, o padre Manoel de Jesus. Por duas ocasiôes o bispo D. fr. João da Cruz oficiou missa na capela, ouvindo Jacinta e Francisca em confissão e administrando-lhes o sacramento da eucaristia. As duas recolhidas arcaram com os custos da construção do edifício sagrado, para o que teriam vendido brincos e joias pessoais, auxiliadas com as esmolas do governador do Rio de Janeiro. ${ }^{23}$ Ainda que já houvesse nesse momento algum plano para a construção de um novo Convento, o mesmo foi

\footnotetext{
${ }^{19}$ B. da S. LISBOA, Annaes, p. 399. Grifos meus.

${ }^{20} \mathrm{~J}$. L. SÁNCHEZ LORA, Mujeres, conventos y formas de la religiosidad barroca, p. 407-412.

${ }^{21}$ W. de S. MARTINS, D. Domingos do Loreto Couto e a construçáo de modelos de santidade feminina na época colonial In: Revista do Mestrado de História, p. 193-229. S. C. C. de ALMEIDA, O sexo devoto, p. 261-268.

${ }^{22}$ Fr. N. de SÃO JOSÉ, Vida da serva de Deus, p. 43.

${ }^{23}$ B. da S. LISBOA, Annaes, t. VII, p. 398-99; Fr. N. de SĀO JOSÉ, Vida da serva de Deus madre Jacinta de Säo José, p. 43-45; Convento de Santa Teresa, p. 7-8.
} 
adiado devido à saída do bispo D. fr. João da Cruz do Rio de Janeiro, e à morte de fr. Manoel de Jesus, confessor e diretor de consciência de Jacinta, que, adoecendo em setembro de 1745 , faleceu em dezembro do referido ano, sendo sepultado na igreja dos padres carmelitas observantes da cidade. ${ }^{24} \mathrm{~A}$ decisão de construção do Convento só foi tomada em 1748, por iniciativa do governador Gomes Freire de Andrade, que já tinha ajudado Jacinta a adquirir a Chácara da Bica e a capela do Menino Deus. Os cronistas-hagiógrafos divergem sobre quem teria sugerido a mudança da sede do novo Convento da Chácara da Bica para a antiga capela de Nossa Senhora do Desterro. Enquanto Baltazar da Silva Lisboa indica que a ideia teria partido de Jacinta, as outras fontes, de modo mais convincente, relacionaram a mudança à iniciativa do governador do Rio de Janeiro, que se ofereceu, inclusive, para construir o Convento com recursos próprios. A pedra fundamental do futuro Convento de Santa Teresa foi lançada com grande solenidade em 24 de junho de $1750 .{ }^{25}$ Assim, se concretizou em parte o antigo plano dos religiosos carmelitas descalços e do ermitão Manoel Correa, de estabelecerem uma fundação conventual no Rio de Janeiro. Com a diferença que se destinava, então, a receber freiras, e não os membros do ramo masculino da Ordem.

Será deixado de lado aqui o longo conflito que Jacinta de São José travou com o bispo do Rio de Janeiro D. fr. Antônio do Desterro Malheiros, no intuito de obter a aprovação da Regra da Reforma de Santa Teresa para a fundação principiada no morro do Desterro, para voltar a tratar de outros agentes que marcaram a trajetória espiritual de Jacinta nos primeiros anos de vocação religiosa. A historiografia acerca da beata mística tem dado pouca importância às relaçóes que manteve com os religiosos capuchinhos italianos, ou barbadinhos, como aparecem mencionados em algumas fontes. Tal como os carmelitas descalços, aqueles missionários rondavam a cidade do Rio de Janeiro em princípios do século XVIII, com a finalidade de estabelecer um hospício, isto é, uma pequena fundação conventual com número reduzido de frades. Os capuchinhos italianos - assim como os capuchinhos franceses, que os tinham precedido - constituíam a única ordem religiosa a atuar no território português sob a direção da Congregação da Propaganda Fide, que a partir de 1622 passou a coordenar em Roma a atividade missionária em escala global. ${ }^{26}$ Eram, assim, missionários da Propaganda e não do Padroado, ainda

\footnotetext{
${ }^{24}$ B. da S. LISBOA, Annaes, t. VII, p. 443.

${ }^{25}$ B. da S. LISBOA, Annaes, t. VII, p. 454; Fr. N. de SÃO JOSÉ, Vida da serva de Deus, p. 91-92; Convento de Santa Teresa, p. 10.

${ }^{26}$ Pe. A. RUBERT, Historia de la Iglesia en Brasil, p. 221, 296 e 337; G. MARTINA, A era do absolutismo, p. 312-314. C. C. BOSCHI, Ordens religiosas, clero regular e missionação no Brasil. In: F. BETHENCOURT e K. CHAUDURI (dir.), História da expansão portuguesa, v. 3, p. 300-301. C. R. BOXER, A Igreja e a expansão ibérica (1440-1770), p. 102.
} 
que a atuaçáo dos mesmos se subordinasse às diretrizes das autoridades régias. Os cronistas da Ordem assinalam que fr. Jerônimo de Montereale e fr. Antônio de Perúgia tinham aportado no Rio de Janeiro em maio de 1721, com destino às missóes na Ilha de São Tomé. ${ }^{27}$ Foram persuadidos pelo governador Aires Saldanha de Albuquerque a permanecerem na cidade, fixando-se inicialmente no Palácio Episcopal da Conceição e, após 1725, no hospício fundado por Francisco de Seixas da Fonseca e por um grupo de terceiros franciscanos. ${ }^{28}$ Após a venda do hospício, em 1729, os capuchinhos foram provisoriamente estabelecidos pelo bispo D. fr. Antônio de Guadalupe em casas arruinadas, próximas à ermida de Nossa Senhora do Desterro. O governador Luís Vahia Monteiro, sucessor de Aires Saldanha, apresentou em 1729 à soberania régia uma informação muito favorável dos capuchinhos, chamando-os de "dois pedaços do céu" que "foram aqui lançados, como Jonas, nas praias de Nínive", destacando o zelo das missóes que efetuavam nas regiôes das Minas e de São Paulo, como também a pobreza exemplar. ${ }^{29}$ A representação do governador não sensibilizou os franciscanos observantes estabelecidos no Convento de Santo Antônio do Rio de Janeiro que, por meio do procurador da província, tentaram invalidar a pretensão dos capuchinhos de se fixarem na ermida do Desterro:

Tem o suplicante notícia que os ditos Religiosos barbadinhos, sendo-lhe presente que V. Majestade mandara informar sobre esta representação, procuraram [...] perpetuar-se em a sua residência e hospício, valendo-se para esse efeito de Contas, súplicas e representaçóes afetadas da Câmara e Governo da Cidade e das Minas, os quais movidas pelo empenho de pessoas poderosas e em ódio das mais Religiôes, fazem o capricho de conservar e sustentar em aquele estado aos ditos Religiosos Estrangeiros.

Nem tão bem se deve dar retenção à introduzida e afetada súplica do Senado da Câmara do Rio de Janeiro, [...] pois se esquecem os Ministros daquele Senado de que em o princípio que os Religiosos da Província suplicante fundaram Conventos em aquela Cidade e Capitania, fizeram com eles contrato de não admitirem Irmandade, Confraria, Igreja ou Ermida que tivesse a denominação de São Francisco ou Santo Antônio, por evitarem que disso se náo seguisse prejuízo das esmolas aos Religiosos fundadores. ${ }^{30}$

\footnotetext{
${ }^{27}$ Fr. J. de PALAZOLLO, O. F. M. Cap., Crônica dos capuchinhos do Rio de Janeiro, p. 55-71. M. da NEMBRO, O. F. M. Cap., Storia dell'attivitá missionária dei minori cappuccini nel Brasile (1538? - 1889), p. 111.

${ }^{28}$ W. de S. MARTINS, Membros do corpo mistico, p. 429-465, a respeito da divisão da Ordem Terceira de São Francisco.

${ }^{29}$ Fr. J. de PALAZOLLO, O. F. M. Cap., Crônica dos capuchinhos do Rio de Janeiro, p. 64.

${ }^{30} \mathrm{AHU}, \mathrm{RJ}, \mathrm{cx} .29$, doc. 23 (cx. 28, d. 2931), doc. cit.
} 
Assim, os religiosos franciscanos observantes alegavam o monopólio de serem os únicos representantes legítimos de São Francisco no Rio de Janeiro, para tentar impedir a fundação dos frades menores capuchinhos. ${ }^{31}$ Não obstante, em 1739, a soberania régia autorizou a construção de um "bumilde hospício, com sua capelinha", destinado aos padres barbadinhos. A pedra fundamental da nova fundação foi lançada em 1740 e o templo anexo dedicado a Nossa Senhora da Oliveira. As informaçóes anteriores levam a crer que ficaram, ainda, alguns na antiga ermida administrada pelo ermitão Manoel Correa, possivelmente esperando a conclusão do novo templo, situado "no caminho que vai para o Desterro" (atual rua Evaristo da Veiga). ${ }^{32}$

Por mais de um ano e meio, Jacinta confessou-se com o padre frei Jacinto de Foligno, religioso capuchinho. De acordo com os cronistas da Ordem, chegara ao Rio de Janeiro em 1738, trazendo a bula de ereção da Prefeitura Apostólica dos capuchinhos. Segundo pode ser apurado em uma carta dirigida aos inquisidores em 10 de novembro de 1744 pelo fr. Manoel de Jesus, carmelita descalço, frei Jacinto fora o segundo confessor de Jacinta de São José. Esta o procurara por indicação do padre Antônio Ferreira, coadjutor da freguesia da Candelária, que julgava o religioso capuchinho com mais "ciência" e "experiência do que ele tinha para a direção de tal alma”. De acordo ainda com a informação citada, o capuchinho deixou a direção espiritual de Jacinta a pedido do prelado da Prefeitura Apostólica, que o enviou "a uma missão muito longe". ${ }^{33}$ Depois disso, a função de confessor e diretor espiritual foi assumida pelo frei Manoel de Jesus. A crônica de Balthazar da Silva Lisboa mostra em dois momentos a culpa sentida por Jacinta por ocasião da mudança de confessores. Nas duas passagens assinaladas, Jacinta experimentava um sentimento de ingratidáo pelo padecimento que causara a frei Jacinto de Foligno. ${ }^{34}$ A documentação do Santo Ofício acrescenta outras informações a esse episódio pouco analisado. Em data não determinada, frei Jacinto apresentou-se ao comissário do Santo Ofício da cidade do Rio de Janeiro, que, naquela ocasião era o cônego arcediago da Sé, confessando "cheio de vergonha as minhas culpas". $\mathrm{Na}$ atividade de confessor, ensinava a Jacinta as doutrinas necessárias "para o seu proveito espiritual, contentamento de sua e minha alma”. Frei Jacinto confessava o "muito amor que lhe tinha", "donde se originou a minha desgraça". Jacinta lhe ar-

\footnotetext{
${ }^{31}$ As divisōes entre os observantes e os capuchinhos principiaram no início do século XVI. Em 1619, a Ordem dos Frades Menores Capuchinhos separou-se totalmente da Observância, passando a adquirir um superior geral. Cf. Fr. L. IRIARTE, O. F. M. Cap. História Franciscana, p. 231-279.

${ }^{32} \mathrm{Fr}$. J. de PALAZOLLO, O. F. M. Cap., Crônica dos capuchinhos do Rio de Janeiro, p. 73-76.

${ }^{33}$ ANTT, TSO (Tribunal do Santo Ofício), IL (Inquisição de Lisboa), processo no 4423. Disponível em http:// digitarq.dgarq.gov.pt. Acesso em 29/10/2011.

${ }^{34}$ B. da S. LISBOA, Annaes, t. VII, p. 400 e 406.
} 
gumentou que "não devíamos governarmos pelo nosso coração [sic]", que podia nos conduzir a enganos, ao que frei Jacinto respondeu "que era verdade que deveríamos governarmos pela lei de Deus, mas que também o Coração e a Consciência há [ilegível] próxima de nossas açôes, a qual porém há de se conformar com a mesma Lei de Deus". Frei Jacinto julgava ter deixado Jacinta escandalizada com tais pensamentos. ${ }^{35}$ O documento encontra-se em seguida bastante danificado, sendo possível, não obstante, extrair um fragmento mais substantivo:

Mas claro está o erro no que lhe disse, qualmente [sic] era opinião dos Morais que dar ósculos e abraços in signum sinceri affectus não era pecado por[que] não reparando cego, muito culpado, que no tempo em que isto falava, ósculos e abraços não podiam passar sem grande culpa.

Ela amante da verdade e da retidão passou-se a outro confessor, do que [ilegível] queixei-me, mas não já porque quisesse continuar a ser mau, mas pela consolação que tinha minha alma em tratar daquele espírito. ${ }^{36}$

Há um comentário ao lado da última passagem, aparentemente acrescentado pelo próprio frei Jacinto, que informava "não atendeu ela por nenhum modo as minhas queixas, mas sempre foi continuando com o seu confessor". O último documento analisado deixa entrever outros motivos para o afastamento do religioso capuchinho, além dos trabalhos missionários. Até onde é possível compreender a fonte fragmentária, frei Jacinto parece ter sentido um afeto incomum pela beata a quem cabia dirigir espiritualmente. Tal sentimento envolvia inclusive atração física, o que de modo algum era adequado em uma relação entre um diretor espiritual e uma mulher que se iniciava na vida de contemplação. Depois do ocorrido, fr. Manoel de Jesus, o novo diretor espiritual, informou ao Santo Ofício que tinha privado Jacinta "de falar nem de dar entrada na sua quinta ao dito Padre Fr. Jacinto, que algumas vezes com licença minha e de seus prelados a ia ver" ${ }^{37}$ Naturalmente, as fontes de caráter hagiográfico e institucional silenciam o mencionado episódio. Os cronistas capuchinhos narram que frei Jacinto "era de uma piedade que edificava a todos. Passou a maior parte da vida missionando cidades e pequenas povoaçôes. Foi sempre muito assíduo no confessionário, e pronto para atender aos chamados doentes". Segundo a mesma crônica, Jacinto falecera em 1778 no Rio de Janeiro, quarenta anos após chegar à cidade, experimentando uma morte gloriosa: "as suas virtudes eram tão patentes que, quando morreu, muita gente fez questão de possuir qualquer

\footnotetext{
${ }^{35}$ ANTT, TSO, IL, processo no 4423, f. 10.

${ }^{36}$ ANTT, TSO, IL, processo no 4423, f. 10.

${ }^{37}$ ANTT, TSO, IL, processo no 4423 , f. 4.
} 
coisa que lhe tivesse pertencido. Consta que, tendo-se aplicado a alguns cegos as relíquias deste santo religioso, recuperaram logo a vista". ${ }^{38}$

Jacinta não manteve contato apenas com os religiosos carmelitas descalços e os capuchinhos. A sua fama atraiu também atenção dos padres da Companhia de Jesus do Colégio do Rio de Janeiro. Em ofício que enviou em 20 de dezembro de 1754 ao secretário de Estado Diogo de Mendonça, o governador Gomes Freire de Andrade revelou que soubera pela primeira vez da existência de Jacinta e de Francisca a partir das informaçóes do padre jesuíta Luiz Tavares, de "virtude exemplar" ${ }^{39}$ Segundo Serafim Leite, Luiz Tavares foi visitador e decano dos estudos do Colégio do Rio de Janeiro. Destacou-se particularmente na prática da caridade, tendo adquirido o cognome de "Pai dos Pobres", e nos exercícios de devoção, em que "passava de joelhos, em oração, três, quatro horas diante do Santíssimo Sacramento". Por praticar jejuns com austeridade, "veio a enfraquecer-se tanto que faleceu no seu Colégio do Rio, a 13 de junho de 1745 " ${ }^{40}$ Torna-se significativo verificar que Jacinta se cercara de clérigos filiados a diversas ordens religiosas, sem falar nos sacerdotes do clero secular, que serão referidos mais adiante.

Para concluir a análise da inserção de Jacinta de São José no campo religioso do Rio de Janeiro setecentista, cabe referir o seu pertencimento à Ordem Terceira de São Francisco. Em 10 de junho de 1735, anos antes de decidir recolher-se na Chácara da Bica, formando o Recolhimento do qual seria a regente, Jacinta professou na associaçáo dos terceiros franciscanos da cidade do Rio de Janeiro. ${ }^{41}$ As informações disponíveis indicam que se tratava de uma devoção familiar, presente especificamente no tronco materno. A mãe de Jacinta, Maria de Lemos Pereira, havia ingressado na Ordem em 4 de outubro de $1708 .{ }^{42} \mathrm{O}$ tio materno de Jacinta, o sacerdote Luís de Lemos Pereira, chegou a ocupar em 1723 o cargo de ministro - o mais elevado - da Ordem Terceira de São Francisco. Naquela ocasião, a associação franciscana vivia uma profunda crise institucional, marcada pela divisão da Ordem em dois grupos, estando Luís de Lemos Pereira vinculado aos "terceiros dissidentes" liderados por Francisco de Seixas da Fonseca. ${ }^{43} \mathrm{~A}$ irmã Francisca Rodrigues Aires (que, na Chácara da Bica, passara a denominar-se de Francisca Maria de Jesus) muito provavelmente também pertencia à Ordem, embora o respectivo assento de entrada não tenha sido encontrado. Esta quase certeza provém de informações dos

\footnotetext{
${ }^{38}$ Fr. M. REZENDE e FR. F. M. PRIMERIO, O. F. M. Cap., Os missionários capuchinhos no Brasil, p. 133. Cf. também Fr. F. PRIMERIO, Capuchinhos em Terras de Santa Cruz nos séculos XVII, XVIII e XIX, p. 226.

${ }^{39} \mathrm{AHU}, \mathrm{RJ}, \mathrm{CA}$, no. 17555.

${ }^{40}$ Pe. S. LEITE, S. J., História da Companhia de Jesus no Brasil, t. VI, p. 19-20.

${ }^{41}$ Arquivo da Venerável Ordem Terceira de São Francisco do Rio de Janeiro (AVOTSF), Livro 1º de Irmãs, f. 98.

${ }^{42}$ AVOTSF, Livro $1^{\text {a }}$ das irmãs, f. 124.

${ }^{43}$ W. de S. MARTINS, Membros do corpo mistico, p. 429-465.
} 
cronistas a respeito do falecimento de Francisca em 13 de julho de 1748, quando não havia ainda completado trinta anos de idade. ${ }^{44}$ No dia da morte, o médico Francisco Correa Leal verificou a flexibilidade do corpo de Francisca e ainda outro prodígio, "que afirmava ser cousa sobrenatural, por abrir e fechar as pestanas sem a menor violência" ${ }^{45}$ No dia seguinte, outro médico, Antônio Antunes, tendo examinado o cadáver e igualmente constatado sinais de santidade heroica, levou o fato ao conhecimento do bispo D. Antônio do Desterro. ${ }^{46}$ Nesse meio tempo,

Com o boato destes sucessos, correram os terceiros de São Francisco a buscar o cadáver para o sepultar na sua ordem, visto ser ela terceira; porém Jacinta, vendo aproximar-se o termo de ser privada da consolaçáo de ter na sua $\mathrm{Ca}-$ pela o corpo de sua irmã, com viva fé em Deus assim falou para o cadáver: - Francisca, veste-se da corrupçáo: - e a esta voz desapareceram todos aqueles gloriosos sinais, tornando-se hediondo e fétido o cadáver. ${ }^{47}$

Segundo o relato hagiográfico, a intervenção de Jacinta foi decisiva para que, sustando provisoriamente os sinais miraculosos do corpo da irmá, conseguisse inumá-la na Capela do Menino Deus da Chácara da Bica em 15 de julho de 1748, frustrando os planos da Ordem Terceira de São Francisco.

$\mathrm{O}$ ingresso nas ordens terceiras franqueava aos leigos a possibilidade de praticarem uma vida religiosa mais intensa que o comum dos fiéis. Os estatutos locais dos terceiros franciscanos fluminenses, confirmados em 1686, prescreviam aos irmãos a frequência à capela da Ordem durante: as cerimônias de entrega do hábito e da profissão; a festa da impressão das Chagas; todos os domingos de cada mês; a Quarta-feira de Cinzas; a Semana Santa; a festa de Santa Isabel; e outras funçôes "que ordena a Regra e os estatutos gerais". ${ }^{48}$ Estes últimos documentos prescreviam a presença dos irmãos terceiros em inúmeros atos de confissão, jejuns, comunhóes gerais e exercícios da via-sacra ao longo do ano. ${ }^{49}$ Ainda que posteriormente Jacinta e Francisca tenham construído uma nova identidade religiosa em torno da espiritualidade de Santa Teresa, é possível conjecturar que a filiação à Ordem Terceira de São Francisco tenha contribuído para reforçar as práticas

\footnotetext{
${ }^{44}$ C. RHEINGANTZ, Primeiras famílias do Rio de Janeiro (séculos XVI e XVII), v. I, p. 63.

${ }^{45}$ B. da S. LISBOA, Annaes, t. VII, p. 447. Fr. N. SÃO JOSÉ, Vida da serva de Deus madre Jacinta de São José, p. $84-86$.

${ }^{46} \mathrm{~A}$ respeito da relação entre os sinais de morte gloriosa e o ideal de santidade heroica, cf. J. L. SÁNCHEZ LORA, Mujeres, conventos y formas de la religiosidad barroca, p. 433-453.

${ }^{47}$ B. da S. LISBOA, Annaes, t. VII, p. 449.

${ }^{48} \mathrm{~W}$. de S. MARTINS, Membros do corpo mistico, p. 129-130.

${ }^{49}$ Fr. D. de la SOLEDAD, Sol Seraphico, p. 860ss, Fr. A. HAZA, Estatutos de terceros, p. 1-12.
} 
religiosas de ambas. A tradicional vinculação de beatas às ordens terceiras pode ter inclusive despertado nas duas irmãs o interesse em seguir o referido modo de vida.

\section{Indo além da hagiografia: a família e os primeiros anos de Jacinta Rodrigues Aires}

Em prefácio à obra Jardim de Portugal, na qual frei Luís dos Anjos compendiou, em 1626, diversos relatos de mulheres portuguesas que tinham adquirido reputação de santidade, Maria de Lurdes Correia Fernandes tece algumas consideraçôes sobre os "escritos de vida". Afastando-se da concepção contemporânea de biografia, a autora observa a influência dos modelos hagiográficos e dos exempla no interior daquelas narrativas de virtudes femininas. ${ }^{50}$ Octavio Paz, na obra que dedicou à trajetória de sóror Juana Inés de la Cruz, avaliou criticamente que o relato de caráter hagiográfico do jesuíta Calleja teria produzido uma freira "ideal”, afastada das tensões familiares e dos conflitos provocados pelas suas ambiçóes intelectuais: "o relato de Calleja não é uma verdadeira biografia, no sentido moderno da palavra, mas uma narração edificante na qual os mínimos incidentes de sua vida são signos e sinais sobrenaturais de sua ascensão rumo à santidade e à virtude. ${ }^{51}$ Sem procurar dar sequência às citaçóes, importa sublinhar que, nos relatos de Balthazar da Silva Lisboa, na Vida de frei Nicolau de São José e nas crônicas do Convento de Santa Teresa, as informaçóes tocantes à infância de Jacinta já indicavam o seu destino de mulher de vida santa e de fundadora do Carmelo Descalço fluminense. Para tentar escapar dos condicionamentos da narrativa hagiográfica, serão analisadas fontes de outra natureza, a partir das quais é possível recuperar a humanidade de Jacinta. Colocadas ao lado dos fragmentos documentais, as narrativas hagiográficas de santidade revelam também novos significados.

Acerca da família de Jacinta, frei Nicolau de São José observava que "seus pais, nobres pela posiçấo social e sentimentos religiosos, foram José Rodrigues Aires, natural do Porto, e D. Maria de Lemos Pereira, do Rio de Janeiro. Católicos praticantes e fervorosos, proporcionaram a seus quatro filhos, Sebastiāo, Antônio, Jacinta e Francisca uma esmerada educação cristã". O primeiro escolhera a vocação eclesiástica, tendo depois acompanhado as duas irmãs no Recolhimento da Chácara da Bica, o segundo o estado o estado de casado, enquanto as duas últimas se dedicaram "ao serviço do Senhor". Revelou ainda que o Jacinta tinha nascido em 15 de outubro de 1715, no dia em que a Igreja festeja Santa Teresa d'Ávila, sendo batizada em 6 de novembro do mesmo ano. O cronista assinalou a "coincidência misteriosa" do

\footnotetext{
${ }^{50}$ M. L. C. FERNANDES, Prefácio. In: Fr. L. dos ANJOS, O.F.M., Jardim de Portugal, p. 10-12.

${ }^{51}$ O. PAZ, Sóror Juana Inés de la Cruz, p. 97.
} 
dia do nascimento de Jacinta, deduzindo daí uma relação de causa e efeito: "por este motivo dedicou-lhe uma singular devoção tomando-a por sua protetora e modelo, sendo pela santa mais duma vez milagrosamente amparada e favorecida". ${ }^{2}$

Os estudos genealógicos, sem contrariarem as informaçóes dos cronistas, acrescentam mais informaçóes para o conhecimento do meio familiar de Jacinta. Maria de Lemos Pereira e José Rodrigues Aires casaram-se em 23 de julho de 1708, conforme registrou o segundo livro de casamentos da freguesia da Candelária. $\mathrm{Na}$ ocasiáo, a mãe de Jacinta contava com pouco menos de 25 anos, enquanto o pai tinha por volta de trinta. Os pais de Jacinta tiveram no total oito filhos, todos batizados na freguesia da Candelária, à exceção de um. ${ }^{53}$ É interessante constatar o silêncio dos cronistas em relação à metade da prole do casal, que poderia, por exemplo, ter sido vitimada pela mortalidade infantil, bem como o critério de seleção utilizado na crônica: foram referidos apenas os filhos que haviam escolhido servir o Senhor e um que se casara, "perpetuando no seio de sua família os costumes e virtudes que copiara de seus pais" ${ }^{54}$ Esse pequeno exemplo demonstra a filtragem operada pela narrativa hagiográfica, deixando de lado fatos que não contribuíam para reforçar a vocação prévia de santidade e o caráter edificante da narrativa. Conforme assinalou Leila Algranti, em comentário à obra de Giovanni Levi, "o biógrafo seleciona os aspectos da vida do biografado que considera socialmente determinantes e comunicáveis." 55 Outra informação que pode ter sido manipulada nos escritos dos cronistas é a data de nascimento de Jacinta. Se os registros da freguesia da Candelária confirmam a data do batismo indicada pelo cronista, nada consta a respeito da data de nascimento, como era a praxe da época. Em meio a tal indefinição, é provável que o dia natalício de Jacinta tenha sido escolhido pelos próprios cronistas-hagiógrafos, na medida em que tal "coincidência misteriosa" vinha a confirmar a predestinação de Jacinta como devota de Santa Teresa. Tal procedimento foi praticado, por exemplo, nas narrativas edificantes produzidas com vistas à beatificação e à canonização de Rosa de Lima que, reputada pelos seus contemporâneos como uma segunda Catarina de Siena, havia supostamente nascido na data em que a igreja comemorava a festa da Santa italiana. ${ }^{56}$

Pouca informação a mais foi fornecida pelos cronistas a respeito dos pais da beata mística. Relataram apenas que, nos primeiros anos de vida de Jacinta, haviam assumido atitudes opostas diante da precoce vocação de santidade da

\footnotetext{
${ }^{52}$ Fr. N. SÃO JOSÉ, Vida da serva de Deus, p. 14. B. da S. LISBOA, Annaes, t. VII, p. 378-379.

${ }^{53}$ C. RHEINGANTZ, Primeiras famílias do Rio de Janeiro (séculos XVI e XVII), v. I, p. 63.

${ }^{54} \mathrm{Fr}$. N. de SÃO JOSÉ, Vida da serva de Deus madre Jacinta de São José, p. 13.

${ }^{55}$ L. M. ALGRANTI, Livros de devoção, atos de censura, p. 71.

${ }^{56} \mathrm{~F}$. GRAZIANO, Wounds of Love, p. 44-49.
} 
filha. Enquanto Maria de Lemos Pereira chegou a castigar fisicamente Jacinta pelos excessos de devoçáo que demonstrava, José Rodrigues Aires supostamente apoiava a vocação da filha: "quando na ocasiáo do Natal dava de presente à sua filha uns cilícios, ficava tão contente, que não teria trocado aqueles instrumentos de penitência pelo mimo mais valioso" ${ }^{57}$ A presença de fatores contrários e, de modo inverso, de elementos propiciadores à vocaçáo precoce de santidade constitui um topos dos relatos deste gênero, identificado por outros estudiosos. A respeito do primeiro ponto, a resistência materna à vocação de santidade é um elemento comum às hagiografias de Jacinta, de Santa Rosa de Lima e de Santa Catarina de Siena. ${ }^{58}$ Mas existe uma informação que leva a pensar que a mãe da beata mística não permaneceria, anos mais tarde, tão oposta aos projetos da filha. No assento de entrada de Maria de Lemos Pereira na Ordem Terceira de São Francisco consta o seguinte: "em o Recolhimento do Desterro" ${ }^{59}$ A considerar verídica tal informação, Maria de Lemos Pereira teria se abrigado no Recolhimento fundado pela filha, o que só poderia ocorrer após 1742 , quando já era uma sexagenária e, muito provavelmente, quando já havia falecido o seu segundo marido.

Existem informações precisas sobre a linhagem materna de Jacinta, enquanto sobre o pai José Rodrigues Aires consta apenas, além da referida data de nascimento, um ano aproximado de morte, 1729. Assim como ocorreu no relato hagiográfico da freira mexicana sóror Juana Inés de la Cruz, o pai de Jacinta era, também, uma "sombra". Ainda com relação ao tronco materno, já foram referidas acima informaçôes respeitantes aos tios Luís de Lemos Pereira, sacerdote e ministro da Ordem Terceira de São Francisco, e o capitão-mor Manoel Pereira Ramos de Lemos Faria, cuja intermediação fora essencial para a aquisição da Chácara da Bica. Pereira Ramos era proprietário dos engenhos de Marapicu, Cabuçu, Itaúna e Gama, entre outros, localizados no recôncavo da baía de Guanabara. Mais tarde, em 1772, os referidos bens foram vinculados, instituindo-se o morgado de Marapicu ${ }^{60} \mathrm{Havia}$ se casado em 1721 com dona Helena de Andrade Souto Maior Coutinho, cuja família se estabelecera no Engenho da Pedra, na localidade de Irajá, desde o início do século XVII. ${ }^{61} \mathrm{O}$ casal formado por Manoel Pereira Ramos e dona Helena de Andrade teve, ao todo, doze filhos, sendo três falecidos em menoridade. $\mathrm{O}$ filho primogênito, João Pereira Ramos de Azeredo Coutinho, o primeiro morgado de

\footnotetext{
${ }^{57}$ Fr. N. de SÃO JOSÉ, Vida da serva de Deus, p. 22-24. A citação encontra-se na última página. B. da S. LISBOA, Annaes, t. VII, p. 382-383.

${ }^{58}$ F. GRAZIANO, Wounds of Love, p. 45. J. L. SÁNCHEZ LORA, Mujeres, conventos y formas de la religiosidad barroca, p. 407.

${ }^{59}$ AVOTSF, Livro $1^{\mathrm{a}}$ das irmãs, f. 124.

${ }^{60}$ M. B. N. da SILVA, Ser nobre na Colônia, p. 190-193.

${ }^{61}$ C. RHEINGANTZ, Primeiras familias do Rio de Janeiro (séculos XVI e XVII), v. I, p. 91-94 e 147.
} 
Marapicu, era desembargador da Casa da Suplicação e deputado da Real Mesa Censória em Lisboa. A prole incluía ainda Clemente Pereira de Azeredo Coutinho e Melo, governador do Maranhão; D. Francisco de Lemos de Faria Pereira Coutinho, bispo de Coimbra; o padre Manoel Pereira Ramos e Faria; e três freiras, havendo uma professado em Portugal, e ficando duas "recolhidas em Santa Teresa do Desterro". ${ }^{62}$ Estas últimas chamavam-se dona Ana de São Francisco, que no século usava o nome de Ana Rosaura Rita de Alarcáo e Luna, que tinha ingressado em 1749 no Recolhimento e saído em 1781 sem professar, e dona Maria da Encarnação, antes denominada Maria de Melo Coutinho e Azeredo. ${ }^{63}$ Por fim, para concluir a análise do tronco materno de Jacinta, deve ser referido o capitáo Bento Pereira de Lemos, que foi pai de Felipa de Santa Teresa, nascida em 1725 e recolhida no Desterro desde 1749, onde veio a falecer como freira. ${ }^{64}$

Do que foi apurado acima, podem-se extrair algumas conclusóes. Em primeiro lugar, a existência, na família extensa de Jacinta, de estratégias de concentração do patrimônio familiar, por meio do estabelecimento de morgadios, que favoreciam o filho primogênito na herança, e do encaminhamento de um número expressivo de filhos para a carreira eclesiástica. No que diz respeito particularmente aos conventos, vários autores já assinalaram o papel chave desempenhado por tais instituições no mercado matrimonial das famílias de elite, que dotavam com bens mais expressivos as filhas destinadas ao casamento. ${ }^{65}$ Em segundo lugar, a presença de várias primas de Jacinta no Recolhimento do Desterro, conferindo àquela fundação um forte traço familiar. Essa percepção torna-se mais ampla ao verificar que Maria da Encarnaçáo ocupou por oito vezes, entre 1781 e 1827, quando o Recolhimento já havia se transformado canonicamente em Convento, o priorado da instituição, cujos mandatos eram trienais. ${ }^{66}$ Assim, tornou-se virtualmente a substituta da madre fundadora, Jacinta. Além das primas e da irmã de sangue Francisca, alguns parentes masculinos de Jacinta prestaram uma valiosa ajuda para garantir o funcionamento do Recolhimento: os padres Sebastiáo Rodrigues Aires, irmão de sangue de Jacinta, que a acompanhou em 1753 na viagem a Portugal para obter o breve apostólico de fundação do Convento, ${ }^{67}$ e José Gonçalves, meio-irmão de Jacinta. Este último sacerdote teve relações mais estreitas com a beata mística, sendo o primeiro a acompanhá-la no Recolhimento da Chácara da

\footnotetext{
${ }^{62}$ M. B. N. da SILVA, Ser nobre na Colônia, p. 194.

${ }^{63}$ C. RHEINGANTZ, Primeiras famílias do Rio de Janeiro (séculos XVI e XVII), v. I, p. 146-147.

${ }^{64}$ C. RHEINGANTZ, Primeiras famílias do Rio de Janeiro (séculos XVI e XVII), v. I, p. 63-64.

${ }^{65}$ S. SOEIRO, The Feminine Orders in Colonial Bahia, Brazil. In: A. LAVRIN (ed.), Latin American Women, p. 173-197. M. LAVEN, Virgens de Veneza, p. 67-83.

${ }^{66}$ Convento de Santa Teresa, p. 53-54.

${ }^{67}$ Fr. N. de SÃO JOSÉ, Vida da serva de Deus, p. 102.
} 
Bica, em 1742. Jacinta conheceu José Gonçalves quando este tinha apenas oito anos, e nesse momento, segundo o frade cronista, "tomou aos seus cuidados esse novo irmão, empenhando-se pela sua educação". ${ }^{6}$

Para concluir a análise do meio familiar de Jacinta, deve-se detalhar a atuação de André Gonçalves dos Santos, pai de um dos principais colaboradores espirituais da beata mística. André casou-se em segundas núpcias em 07 de outubro de 1730 com Maria de Lemos Pereira que, naquela ocasião, também já era viúva. Do seu primeiro casamento, André trouxera três filhos, sendo José Gonçalves o mais velho. ${ }^{69}$ Ao contrário do pai de Jacinta, há uma fartura de informações nas crônicas e nos arquivos sobre seu padrasto. Segundo os cronistas, este também incentivava a vocação religiosa das enteadas Jacinta e Francisca, "apesar de ser a mãe um tanto contrária à vocação das filhas". ${ }^{70}$ Devido ao perfil da família de Jacinta, não se pode dissociar a aludida inclinaçáo religiosa da necessidade daquelas mulheres de adquirirem um estado adequado. No início do vínculo conjugal, o casal André Gonçalves e Maria de Lemos Pereira tinha, no mínimo, sete filhos menores sob a sua custódia, sendo Jacinta a mais velha. ${ }^{71}$ Pressionado por esse conjunto de circunstâncias, André Gonçalves encaminhou uma petição ao Conselho Ultramarino, recebida por este Tribunal em novembro de 1735, expondo que por

óbito de seu antecessor José Rodrigues Aires lhe ficaram duas filhas e enteadas chamadas Jacinta Rodrigues Aires e Francisca Rodrigues Aires, de idade a primeira de dezenove anos e a segunda de dezesseis, as quais têm grande desejo de servir a Deus no estado de Religiosas, por se livrarem dos perigos do Século, e para cumprirem tão santo e virtuoso intento, têm tomado Resolução de passarem a este Reino e nesta Corte escolherem o Convento mais Conveniente àquele fim, e o não podem por em execução sem que Vossa Majestade lhe conceda Licença para se poderem expatriar. ${ }^{72}$

Segundo analisou a historiografia, a partir do Alvará de 10 de março de 1732 o envio de mulheres coloniais para professarem em conventos do Reino deveria

\footnotetext{
${ }^{68}$ Fr. N. de SÃO JOSÉ, Vida da serva de Deus, p. 31. B. da S. LISBOA, Annaes, t. VII, p. 379.

${ }^{69}$ C. RHEINGANTZ, Primeiras famílias do Rio de Janeiro (séculos XVI e XVII), v. I, p. 63. Fr. N. SÃO JOSÉ, Vida da serva de Deus madre Jacinta de São José, p. 30-31.

${ }^{70}$ Fr. N. de SÃO JOSÉ, Vida da serva de Deus, p. 31.

${ }^{71}$ Não foram levados em conta quatro irmãos de Jacinta sobre os quais há apenas os registros de batismo, tendo provavelmente falecido ainda na infância, conforme foi argumentado acima.

${ }^{72} \mathrm{AHU}, \mathrm{RJ}, \mathrm{CA}, \mathrm{n}^{\circ}$ 8700. Requerimento de André Gonçalves, residente no Rio de Janeiro, no qual pede licença para embarcarem para o Reino suas enteadas Jacinta e Francisca Rodrigues Aires, filhas de sua mulher Maria de Lemos Pereira e de seu primeiro marido José Rodrigues Aires (1735).
} 
passar pela permissão das autoridades. ${ }^{73} \mathrm{O}$ Conselho Ultramarino ordenou que o governador do Rio de Janeiro Gomes Freire de Andrade mandasse informaçóes sobre a petição, o qual respondeu: "parece-me atendivel este requerimento, para que Vossa Majestade lhe faça a graça que pretende". ${ }^{74}$ Não foi localizada a consulta do Conselho, com a respectiva resolução do soberano, mas as informaçóes disponíveis levam a crer que a petição de André Gonçalves fora autorizada. Os cronistas narram que, às vésperas da partida para Lisboa, Jacinta sofreu uma queda em que deslocou o quadril, ficando impossibilitada de andar e mesmo de ficar de pé. ${ }^{75}$ Esse acidente teria impedido Jacinta e Francisca de seguirem o desígnio do padrasto.

Depois de trinta anos de serviço nas tropas regulares, no Reino e no Rio de Janeiro, André Gonçalves dos Santos foi provido, em $1^{\circ}$ de março de 1730 , no posto de Comissário de Artilharia da capitania fluminense. ${ }^{76} \mathrm{~A}$ nomeação para o posto não foi suficiente para lhe satisfazer porque, pressionado talvez por necessidades domésticas, voltou em pouco tempo a solicitar novas mercês ao soberano. Em 1732 pedia, em recompensa dos seus serviços, o hábito da Ordem de Cristo para um dos filhos e a tença de cento e cinquenta mil réis por ano, para se repartir pelos outros. ${ }^{77}$ É interessante pensar que, na referida ocasião, os filhos contavam com menos de dez anos de idade, a julgar pelas informaçóes anteriores dos cronistas. Segundo se pode apurar na consulta do Conselho de junho de 1732, o Tribunal autorizara apenas a concessão do hábito da Ordem de Cristo, com rendimento de doze mil réis anuais, e de vinte mil réis para se repartir pelos mais filhos. ${ }^{78} \mathrm{~A}$ longa folha de serviços de André Gonçalves dos Santos incluía, por exemplo: “ir de Socorro à Praça de Gibraltar e Se pelejar com cinco Navios de França”; várias atividades de comboio da frota, entre o Reino e a América Portuguesa; em 1711, talvez em virtude do ataque francês à cidade do Rio de Janeiro, o resgate de várias peças de artilharia dos cascos das naus queimadas; em 1713, novos confrontos com franceses no litoral do Rio de Janeiro; e, em 1724, a partida para Montevidéu e, em seguida, à Colônia do Sacramento, onde trabalhou na fortificação da praça. ${ }^{79}$

\footnotetext{
${ }^{73}$ R. AZZI e M. V. REZENDE, A vida religiosa feminina no Brasil colonial. In: R. AZZI (org.), A vida religiosa no Brasil, p. 24-29. L. M. ALGRANTI, Honradas e devotas, p. 70-71.

${ }^{74}$ ANRJ, Cód. 80, Correspondência dos governadores do Rio de Janeiro, v. 7 (1737-1744), f. 34.

${ }^{75}$ Fr. N. de SÃO JOSÉ, Vida da serva de Deus, p. 33. B. da S. LISBOA, Annaes, t. VII, p. 393.

${ }^{76} \mathrm{AHU}, \mathrm{RJ}, \mathrm{CA}, \mathrm{n}^{\circ}$ 6426-6427. Consulta do Conselho Ultramarino sobre o provimento do posto de Comissário de Artilharia da Capitania do Rio de Janeiro, que vagara por falecimento de Miguel Pais, e a que eram concorrentes André Gonçalves e Miguel Cardoso Ferreira. Lisboa, 1º de março de 1730.

${ }^{77} \mathrm{AHU}, \mathrm{RJ}, \mathrm{CA}, \mathrm{n}^{\circ}$ 7189-7224. Requerimento de André Gonçalves, Comissário geral da Artilharia da Praça do Rio de Janeiro, no qual pede, em recompensa de seus serviços, o hábito da Ordem de Cristo para um dos seus filhos e a tença de cento e cinquenta mil réis por ano, para se repartir pelos outros (1732).

${ }^{78} \mathrm{AHU}, \mathrm{RJ}, \mathrm{CA}, \mathrm{n}^{\circ} 7189$

${ }^{79} \mathrm{AHU}, \mathrm{RJ}, \mathrm{CA}, \mathrm{N}^{\circ} 7189-7224$.
} 
Todas essas atividades vinham certificadas por atestados passados por sucessivos governadores do Rio de Janeiro - Francisco de Távora, Aires de Saldanha de Albuquerque, Luís Vahia Monteiro - e por outros comandantes militares.

A proteção prestada a Jacinta pelo governador Gomes Freire de Andrade pode ter sido uma atitude de reconhecimento pelos contínuos serviços do Comissário de Artilharia André Gonçalves. Além deste, Manoel Pereira Ramos de Lemos e Faria, um dos tios maternos de Jacinta e que tinha relações próximas com Gomes Freire de Andrade, havia executado várias tarefas militares, ficando por onze anos no posto de capitão de infantaria paga, sendo também capitão-mor no distrito de Ribeirão do Carmo, da cidade de Mariana, e das freguesias Marapicu e Juari, "onde disciplinou o seu Terço e armou com homens à sua custa na ocasiäo da guerra da Colônia do ano de 1736". ${ }^{80}$ Tudo isso não descarta o papel assumido por um sacerdote da Companhia de Jesus como elo de aproximação entre Jacinta e o governador do Rio de Janeiro. Depois que começara a administrar a capitania do Rio de Janeiro, em 1733, Gomes Freire de Andrade tinha recomendado ao padre jesuíta Luiz Tavares que lhe informasse sobre algumas pessoas pobres. O sacerdote da Companhia de Jesus comunicou ao Conde de Bobadela que tinha conhecimento

de duas moças que sumamente se edificavam, filhas de um comissário de Artilharia, que ainda àquele tempo viviam sem bastante cômodo: alguns anos foram estas moças socorridas das minhas esmolas e resolvendo-se a observarem vida mais austera e solitária, comprando com esmolas e parte da sua legítima uma casinha e horta junto aonde está fundado o convento, não só se recolheram nela, mas uniram à sua companhia mais oito ou dez meninas, que foram educando. ${ }^{81}$

Essa informação, além de confirmar o estado de relativa pobreza padecido por Jacinta e Francisca, também fornece pistas para esclarecer outros detalhes pouco conhecidos das atividades das enteadas do comissário de Artilharia. Assim, é importante destacar a referência ao uso das legítimas para a aquisição da Chácara da Bica. Consistindo na herança que cabia aos filhos por ocasião do falecimento de algum dos progenitores, ${ }^{82}$ o recebimento da legítima indicaria o óbito do padrasto ou da mãe. Se os registros da Ordem Terceira de São Francisco estiverem certos, ao indicarem a permanência de Maria de Lemos Pereira no Recolhimento do Desterro, fica então presumida a morte de André Gonçalves dos Santos. Essa impressão

\footnotetext{
${ }^{80}$ M. B. N. da SILVA, Ser nobre na Colônia, p. 194.

${ }^{81} \mathrm{AHU}, \mathrm{RJ}, \mathrm{CA}, \mathrm{n}^{\circ}$ 17555. Ofício do governador Gomes Freire de Andrade para Diogo de Mendonça acerca da fundação do Convento de Santa Teresa. Rio de Janeiro, 20 de dezembro de 1754.

${ }^{82}$ M. B. N. da SILVA, Sistema de casamento no Brasil colonial, p. 102.
} 
é reforçada pelo fato de o tio materno Manoel Pereira Ramos encabeçar todo o negócio de aquisição da propriedade, sem referir a participação do comissário de Artilharia. Outro detalhe significativo é a menção à educação de meninas como atividade exercida por Jacinta e Francisca. Talvez o ensino de mulheres possa ter sido uma das finalidades iniciais do Recolhimento do Desterro. Os hagiógrafos informam que, na infância, Jacinta ensinava doutrina religiosa aos escravos da casa dos pais, uma informação que deve ser vista com cuidado. ${ }^{83} \mathrm{Um}$ indício indireto da familiaridade de Jacinta com o mundo dos livros foi o convívio próximo, por anos a fio, com eclesiásticos de sua própria família. Dois filhos de Manoel Pereira Ramos, primos de Jacinta, tornar-se-iam, depois, letrados importantes: João Pereira Ramos de Azeredo Coutinho, nascido em 1722, e Francisco de Lemos de Faria Pereira Coutinho, nascido em $1735 .{ }^{84} \mathrm{O}$ próprio padrasto André Gonçalves tinha gosto pela escrita, o que é revelado por meio da representação que dirigiu à soberania régia em 1730 . $\mathrm{Na}$ ocasião, pediu um estabelecimento adequado para que, como novo comissário, ensinasse "aos artilheiros todo o uso e prática de Artilharia, e como isto não se pode fazer, o que toca à prática, riscar e escrever". ${ }^{5}$ Mas os maiores testemunhos da intimidade de Jacinta com os escritos religiosos aparecem nos relatos de suas visóes, como será visto a seguir.

\section{Jacinta de São José, uma segunda Teresa?}

Nesse item, serão analisadas as visões de Jacinta de São José, que ocupam a parte central das narrativas de Balthazar da Silva Lisboa e do frade Nicolau de São José, bem como alguns fragmentos da documentação do Santo Ofício. Em todas as fontes mencionadas, fica evidente a concentração dos relatos místicos de Jacinta nos anos de 1744 e 1745, quando frei Manoel de Jesus a acompanhava como confessor e diretor de consciência. Um dos cronistas refere que a produção dos escritos da beata mística decorria diretamente da atuação do religioso carmelita descalço, que "Ihe ordenou por obediência declarar o que sucedia". ${ }^{86}$ De modo mais específico, o cronista dos Annaes indicou que "todas estas revelaçóes foram escritas por seu Confessor, e se acham no Arquivo do Convento". A respeito de uma visão que Jacinta tivera em 09 de janeiro de 1745, frei Manoel de Jesus acrescentou uma declaração, transcrita pelo mesmo cronista: "certifico e declaro, e se necessário for jurarei, que a Madre Jacinta de São José me deu conta do sobredito de manhã, o que

\footnotetext{
${ }^{83}$ B. da S. LISBOA, Annaes, p. 383. Fr. N. de SÃO JOSÉ, Vida da serva de Deus, p. 19.

${ }^{84}$ C. RHEINGANTZ, Primeiras famílias do Rio de Janeiro (séculos XVI e XVII), v. I, p. 147-148.

${ }^{85} \mathrm{AHU}, \mathrm{RJ}, \mathrm{CA}, \mathrm{n}^{\circ} 6516$ (1730). Representação de André Gonçalves, Comissário geral da Artilharia da praça do Rio de Janeiro, em que pede uma casa em que possa estabelecer o curso para ensino de artilheiros (1730). ${ }^{86}$ B. da S. LISBOA, Annaes, t. VII, p. 489.
} 
então não escrevi por não poder, guardando a escrita para a tarde, e então mandando-lhe eu que me tornasse a dizer todo o sobredito" ${ }^{87}$ Por sua vez, a documentação do Santo Ofício indica que alguns escritos podiam ter sido lavrados pela própria Jacinta. Em 10 de novembro de 1744, o confessor Manoel de Jesus declarou ao Santo Ofício que, estando já sob a sua obediência, Jacinta

começou a sentir na alma vários impulsos para escrever, e vendo eu que semelhante escrita por impulso do espírito era o melhor fruto que eu podia ter para [ilegível] se a árvore que o dava era boa ou má, como aconselha e ensina o Evangelho, lhe dei licença para que sentindo os tais impulsos os escrevesse, e com efeito movida deles escreveu e vai escrevendo de quando em quando. ${ }^{88}$

Fossem relatos ouvidos da boca de Jacinta e anotados por frei Manoel de Jesus ou narrativas produzidas pela própria beata mística e apenas trasladadas pelo religioso, ou ainda uma combinação de ambas as situaçóes, as fontes deixam patente a interação entre a fundadora do Recolhimento do Desterro e o seu confessor. A escrita feminina de espiritualidade adquiria, na época, um caráter mediado, em virtude da supervisão exercida pelos clérigos, para evitar desvios de doutrina. ${ }^{89}$ Tal função tinha sido particularmente reforçada no decurso do século XVI, por conta do envolvimento de muitas mulheres leigas em correntes de misticismo heterodoxo. ${ }^{90}$ Nas discussóes referentes à escrita feminina, a historiografia assume variados matizes, muitas vezes claramente divergentes. Jean Franco, analisando as revelações produzidas por freiras no século XVII na Nova Espanha, assinalou o estrito controle exercido pelos diretores de consciência e confessores sobre tais narrativas. Sob a supervisão de um panopticon, isto é, da leitura do confessor, haveria pouco espaço de autonomia para a experiência religiosa feminina. Naquelas situaçóes em que o clero utilizava os escritos das mulheres sob a sua direção para elaborarem narrativas de caráter hagiográfico, repletas de exempla ou pequenas anedotas comuns nas vidas de santos, a escrita feminina ficava ainda mais desvalorizada. ${ }^{11}$ Em outro campo se situa a reflexão de Alison Weber, a respeito da obra de Teresa d'Ávila. Segundo a mencionada estudiosa, a freira castelhana conseguiu driblar as restriçóes e suspeitas pendentes sobre a escrita e a condição femininas por

\footnotetext{
${ }^{87}$ B. da S. LISBOA, Annaes, t. VII, p. 441.

${ }^{88}$ ANTT, TSO, IL, processo no 4423, f. 3v.

${ }^{89}$ L. VOLLENDORF, Transatlantic Ties: Women's Writing in Iberia and Americas. In: D. KOSTROUN e L. VOLLENDORF (dirs.), Women, Religion and Atlantic World (1600-1800), p. 79-112.

${ }^{90}$ M. BATAILLON, Erasmo y España, p. 166-190. S. J. da S. DIAS, Correntes de sentimento religioso em Portugal, t. 1, p. 363-407; P. V. B. TAVARES, Caminhos e invenções de santidade feminina em Portugal nos séculos XVII e XVIII (alguns dados, problemas e sugestóes) In: Via Spiritus, p. 163-215.

${ }^{91}$ J. FRANCO, PlottingWomen, p. 3-16.
} 
meio da "retórica da feminilidade". De modo engenhoso, Teresa se apropriou de estereótipos misóginos, reproduzindo-os na sua autobiografia e em outras obras, para garantir o livre desenvolvimento da Teologia Mística. ${ }^{92}$ De forma análoga, para Rosa de Lima, canonizada em 1671, o reconhecimento de "ignorância" diante das manifestações do sagrado e a obediência à hierarquia eclesiástica se conciliaram com a reivindicação de autoridade para sua própria experiência mística. ${ }^{93}$

Como situar a vivência religiosa de Jacinta a partir das balizas historiográficas mencionadas? Por um lado, as visóes de beata mística enquadram-se na experiência da escrita feminina colonial analisada por Jean Franco, na medida em que foram mediadas por vários narradores masculinos: frei Manoel de Jesus (1744-1745), frei João dos Santos (1819), Balthazar da Silva Lisboa (1835) e frei Nicolau de São José (1935). Por outro lado, como será argumentado adiante, é indisfarçável a presença do modelo teresiano na experiência religiosa de Jacinta, notando-se, inclusive, a presença pontual da "retórica da feminilidade". Ainda que Jacinta tenha adquirido uma reputação de santa para muitos de seus contemporâneos, e principalmente para seus hagiógrafos, não consta que tenha sido aberto pela Igreja nenhum processo formal de reconhecimento da sua santidade. Jacinta se situa em plano análogo ao de muitas devotas de Santa Teresa d'Ávila, que, alimentando-se das obras e da espiritualidade desta, não conseguiram obter para as suas práticas o devido reconhecimento eclesiástico, sendo, ao contrário, acusadas de falso misticismo. ${ }^{94}$

Já é o momento de analisar as principais visóes de Jacinta para, a partir daí, relacioná-las com possíveis modelos de devoção. Nos dois suportes principais de informaçóes disponíveis para reconstituir a experiência mística de Jacinta, isto é, os Annaes de Silva Lisboa e a Vida de fr. Nicolau de São José, as visões foram adaptadas à construção de narrativas hagiográficas. ${ }^{95}$ Estas, principiando com a precoce santidade revelada na infância de Jacinta, relatam em seguida os seus progressos e afliçóes espirituais para, entâo, terminarem com a morte gloriosa da beata mística e o reconhecimento canônico do Convento de Santa Teresa do Desterro. Sem sombra de dúvida, praticamente todos os episódios da infância de

\footnotetext{
${ }^{92}$ A. WEBER, Little Women: Counter-Reformation Misogyny. In: D. M. LUEBKE (ed.), The Counter Reformation, p. 144-161.

${ }^{93}$ K. A. MYERS, Redeemer of America: Rosa de Lima (1586-1617), the Dynamics of Identity, and Canonization. In: A. GREER e J. BILINKOFF (eds.), Colonial Saints, p. 267.

${ }^{94} \mathrm{Cf}$. diversos estudos de C. M. BORGES: Las hijas de Teresa de Ávila: espiritualidad mística entre mujeres de la península ibérica y del Brasil colonial. In: M. I. VIFORCOS MARINAS e R. LORETO LÓPEZ (coords.), Historias compartidas, p. 177-193; A conquista do espaço público: o protagonismo feminino nos séculos XVII e XVIII na esfera religiosa. In: C. SARMENTO (coord.), Condição feminina no Império colonial português, p. 265-273; e As mensageiras do Senhor: a situação ambígua das beatas na Península Ibérica - séculos XVI a XVIII In: A. A. F. de ASSIS e M. S. PEREIRA (orgs.), Religióes e religiosidades, p. 15-27.

${ }^{95}$ L. ALGRANTI, Livros de devoção, atos de censura, p. 99 e 107.
} 
Jacinta constituem exempla de conteúdo moralizante e edificante, análogo aos que povoavam as narrativas de vidas de santos, como a Legenda Áurea, o Flos Sanctorum etc. ${ }^{96} \mathrm{~A}$ esse respeito, destacam-se cinco exempla de caráter mais significativo: quando Jacinta foi atirada, sucessivamente, do alto das barreiras situadas nas proximidades do Convento de Santo Antônio e da igreja de Santa Rita; quando foi arremessada pelos ares e atirada na lagoa que existia atrás da igreja de Nossa Senhora do Rosário; quando foi lançada dentro de um forno; e, por fim, quando caiu dentro de um poço. ${ }^{97}$ Nos cinco casos, forças demoníacas haviam ameaçado com gravidade a vida de Jacinta que, não obstante, saiu ilesa de todos os malefícios graças à permanente proteção de Santa Teresa. Sánchez Lora observa que o referido tipo de tormento imposto pelo demônio era muito comum nas narrativas hagiográficas, tornando-se evidente, mais uma vez, a influência deste tipo de narrativa nos escritos de vida sobre as mulheres. ${ }^{98}$ Nas pequenas histórias da beata mística, percebe-se nitidamente o modus operandi da narrativa hagiográfica: protegida desde a infância pela santa de Ávila, a Providência Divina destinava Jacinta a ser a fundadora do Carmelo Descalço no Rio de Janeiro.

Os cronistas referem que os episódios selecionados acima foram revelados por Jacinta ao confessor Manoel de Jesus em $01^{\circ}$ de junho de 1744 . Na ocasiáo, por intermédio de Santa Teresa e de São João da Cruz, os fundadores do ramos feminino e masculino da Ordem do Carmelo Descalço, a beata mística recuperou em uma visão imaginária a memória daqueles acontecimentos de sua infância: "nisto lhe mostraram como num espelho a sua consciência desde menina até o estado atual". ${ }^{9}$ É patente, assim, que as mais significativas lembranças dos primeiros anos de Jacinta foram forjadas bem mais tarde, no período de mais intensa atividade mística, quando estava sob a direção do religioso carmelita descalço. Tais informações esclarecem melhor o trabalho de edição efetuado pelos cronistas-hagiógrafos a partir do material narrativo de primeira mão, ${ }^{100}$ constituído pelas revelaçôes de Jacinta anotadas ou trasladadas pelo confessor Manoel de Jesus. Por outro lado, a reconstrução a posteriori dos primeiros anos de Jacinta efetuada pelas revelaçôes e pelos usos da hagiografia permitem aplicar às narrativas estudadas o comentário formulado por Sánchez Lora: "na obra hagiográfica se desvanecem os

\footnotetext{
${ }^{96}$ H. FRANCO JR., Apresentação. In: J. de VARAZZE, Legenda Áurea, p. 11-25. L. G. PIRES, Para uma leitura intertextual de "Exercícios espirituais" do padre Manuel Bernardes, p. 180-183.

${ }^{97}$ B. da S. LISBOA, Annaes, p. 380-384; Fr. N. de SÃO JOSÉ, Vida da serva de Deus, p. 18-19.

${ }^{98}$ J. L. SÁNCHEZ LORA, Mujeres, conventos y formas de la religiosidad barroca, p. 419.

${ }^{99}$ B. da S. LISBOA, Annaes, p. 384 e 429-430; Fr. N. de SÃO JOSÉ, Vida da serva de Deus, p. 64-66. A citação encontra-se na p. 65 desta última obra.

${ }^{100}$ J. FRANCO, Plotting Women, p. 13-15.
} 
conceitos de espaço, tempo e realidade, para ser substituidos por um espaço sobrenatural atemporal". 101

Outras visóes produzidas no momento de atuação do confessor Manoel de Jesus reforçaram a vinculação espiritual de Jacinta a Santa Teresa. Balthazar da Silva Lisboa narra que, durante um dos êxtases, Jacinta fora chamada por Cristo e transportada a "certa terra do Brasil, onde fora levada para salvar da eterna morte a um Religioso Carmelita observante, que por desesperação estava para se enforcar em um cordel fino". Jacinta dissuadiu o frade de cometer ato táo pecaminoso, assim como preveniu uma religiosa da mesma Ordem a se preparar para o momento de morte, senão correria o risco de morrer em pecado mortal. ${ }^{102}$ É impossível não relacionar as intervençóes reparadoras de Jacinta à ação de Teresa d'Ávila no intuito de reformar o Carmelo da Observância, que a levou, a partir daí, a fundar uma nova ordem religiosa. ${ }^{103}$ Em outra viagem imaginária, Jacinta foi levada em espírito por Santa Teresa ao Purgatório, de onde as almas de duas religiosas foram tiradas, "as quais viram subir ao Céu" ${ }^{104}$ De modo semelhante, na autobiografia de Santa Teresa, há o relato de como o Senhor a havia conduzido em espírito, durante a oração, ao Inferno. ${ }^{105}$ Presentes no imaginário do Ocidente cristão desde princípios da Idade Média, as viagens ao Purgatório se mesclam nas visóes de Jacinta à geografia sagrada da América Portuguesa, aproximando-se do gênero narrativo dos relatos de viagem. ${ }^{106} \mathrm{~A}$ visão que indica o vínculo mais estreito entre a beata mística e o seu supremo modelo de devoção foi registrada em 09 de setembro de 1745. Quando considerava a "grande glória que resultaria para Deus" a fundação de um "Convento da Reforma de Santa Teresa", perdeu os sentidos ao mirar uma estampa da referida santa. A partir daí, ambas "começaram a suplicar a Nosso Senhor que, tendo-lhe prometido pessoas para formar a comunidade, lhes concedesse ainda os socorros materiais para edificação do Convento projetado" ${ }^{107}$

Deixando de lado outras visões de menor peso no interior das duas narrativas hagiográficas, devem ser destacadas as apariçôes do Menino Jesus a Jacinta. Logo em seguida à fixação desta, de Francisca, e dos padres Sebastiâo Rodrigues Aires e José Gonçalves na Chácara da Bica, a beata mística tomou a iniciativa de construir ali uma capela com a invocaçáo do Menino Deus, em 1743, como referido. O fato indica, por si só, a importância assumida por aquela devoção no conjunto

\footnotetext{
${ }^{101}$ J. L. SÁNCHEZ LORA, Mujeres, conventos y formas de la religiosidad barroca, p. 421.

${ }^{102}$ B. da S. LISBOA, Annaes, p. 415-416. Fr. N. de SÃO JOSÉ, Vida da serva de Deus, p. 67-68.

${ }^{103}$ T. de JESUS, Livro da vida. In: Obras completas, p. 19-291.

${ }^{104}$ B. da S. LISBOA, Annaes, p. 416. Fr. N. de SÃO JOSÉ, Vida da serva de Deus, p. 68.

${ }^{105}$ T. de JESUS, Livro da vida, p. 214-222.

${ }^{106} \mathrm{~J}$. LE GOFF, O nascimento do Purgatório, p. 132-138. E. S. V. TUDELA, Colonial Angels, p. 1-13.

${ }^{107}$ Fr. N. de SÃO JOSÉ, Vida da serva de Deus, p. 74.
} 
das práticas religiosas de Jacinta. Desde a Baixa Idade Média, o culto à infância de Cristo, entre outras modalidades sensíveis de devoção, havia se disseminado na Cristandade Ocidental, indicando uma recepção maior dos fiéis à dimensão terrena do Salvador. ${ }^{108}$ Tal gênero de devoçâo atraiu, acima de tudo, o interesse das mulheres, cujas vivências do sagrado passavam, quase sempre, pelos sentidos do corpo, pela experiência da maternidade etc. ${ }^{109}$ No período moderno, pode ser observado um prolongamento das referidas tendências devocionais, exemplificadas, por exemplo, no culto às Chagas de Cristo, ao Sagrado Coração de Jesus, à Paixão etc. Segundo Jacques Gélis, na época em foco a devoção ao Menino Jesus se tornou particularmente associada às carmelitas: "depois que Teresa de Avila doou uma estátua do Menino Jesus ao mosteiro de Villanueva de la Xara, impôs-se a tradição de doar uma dessas imagens a toda nova fundação". ${ }^{110}$

Era muito intensa a devoção que Jacinta dirigia à representação de Cristo na infância. Em prolongadas visóes, a beata mística dialogava com o Menino Deus, fazia-lhe agrados e, prova máxima do vínculo afetivo existente entre ambos, mantinha-o guardado dentro de seu coração. Em 23 de maio de 1744, véspera de Pentecostes, o Menino Deus apareceu-lhe e, tremendo de frio, lhe disse: " - Filha, dai-me agasalho. Entendendo que o Senhor falava das celinhas que andava fazendo na sua casa para se recolher e fechar-se com sua irmã, lhe disse, Senhor, escolhei a que quiserdes, e este lhe tornou - Esta é a que eu tenho escolhido. Ele entrou pela ferida do coração, abrindo-a e rasgando-a muito mais, e apenas entrou se fechou para descansar." "111 O sentimento da presença íntima de Jesus aparece também na outra crônica: "mais de uma vez ouviu a voz suave dizer-lhe: 'Minha filha, estou contigo!', e também teve a ventura de vê-Lo escondido no interior da alma em forma de amável e lindo Menino". ${ }^{112}$ Essa maneira de experimentar a presença de Cristo pode ter sido adquirida a partir da leitura dos escritos de Santa Teresa, que uma vez assinalou "eu rezava assim: como não podia raciocinar com o intelecto, esforçava-me por representar a Cristo dentro de mim, e sentia-me melhor". ${ }^{113}$ Uma experiência mais complexa ocorreu com Jacinta em 22 de dezembro de 1744, quando estava preparando a capela para a festa do Natal. O relato revela como a contemplação de imagens podia estimular as visóes místicas:

\footnotetext{
${ }^{108}$ A. VAUCHEZ, A espiritualidade na Idade média ocidental, p. 125-149.

${ }^{109}$ M. KING, A mulher no Renascimento, p. 127-140. E. KESSEL, Virgens e mães entre o céu e a terra. In: A. FARGE e N. Z. DAVIS (dirs.), Do Renascimento à Idade Moderna, p. 215.

${ }^{110}$ J. GÉLIS, O corpo, a Igreja e o sagrado. In: G. VIGARELLO (dir.), Da Renascença às Luzes, p. 50.

${ }^{111}$ B. da S. LISBOA, Annaes, p. 428.

${ }^{112}$ Fr. N. de SÃO JOSÉ, Vida da serva de Deus, p. 72.

113 T. de JESUS, Livro da vida, p. 67.
} 
Viu em visão imaginária a mesma imagem do Menino Jesus sobre o trono da capela de que é o orago[...] e que, rindo-se para ela, dizia: - Deixa-te, filha. E tirando do braço uns maços de papéis lhos mostrou, e conhecendo serem todos de sua letra, disse para o Senhor: - Bendito sejais, que o tenhais convosco; que vosso seja tudo, o que de vós e por vós escrevo. E dando o Senhor Menino uma risada, subiu para seu lugar, olhando-se e rindo-se, com o que tornou a si, e viu o trono já enfeitado, persuadida que no tempo em que estivera fora de si o estivera armando. ${ }^{114}$

Para Teresa d'Ávila, a leitura de obras sagradas e a contemplação de imagens serviam de ponto de partida para os quatro graus de oração. No início da trajetória espiritual, a santa confessava que "não teria conseguido perseverar na oração nos dezoito anos em que me acometeram tamanhos sofrimentos e aridez, visto não poder fazer oração discursiva, sem as leituras". ${ }^{115}$ Um pouco mais adiante, detalhava: "tinha tão pouca habilidade para representar coisas com o entendimento que, se não fosse o que via, não me adiantava nada a imaginação, como fazem outras pessoas que conseguem fazer representaçóes onde se recolhem [...]. Por causa disso, era tão amiga de imagens". ${ }^{116}$ Aparentemente, Jacinta seguiu um caminho semelhante, apoiando-se na materialidade das imagens e na leitura de obras de conteúdo místico para alcançar visões imaginárias e revelações. Com relação ao segundo ponto, Leila Algranti mapeou as possíveis leituras de Jacinta com base em listas de livros antigos existentes na biblioteca do Convento de Santa Teresa do Rio de Janeiro. ${ }^{117}$ Aqui será adotado um procedimento diferente. Avaliar o modo como Jacinta se apropriou da literatura mística implica necessariamente o cotejamento dos escritos atribuídos à beata com as obras de Santa Teresa e de outros modelos de espiritualidade do século XVI.

Em uma conhecida passagem do Livro da Vida, Teresa d'Ávila comparou o aperfeiçoamento da vida de oração à atividade de irrigar um jardim, que podia ser feita de quatro maneiras, em ordem crescente de eficiência e decrescente de dispêndio de energia: por meio da água tirada de um poço, de uma roda d'água e canaleta, de um rio ou riacho e de uma chuva abundante. ${ }^{118} \mathrm{Em}$ um escrito

\footnotetext{
${ }^{114}$ B. da S. LISBOA, Annaes, p. 437-438. Muito mais resumido, o relato aparece também em Fr. N. de SÃO JOSÉ, Vida da serva de Deus, p. 75.

${ }^{115}$ T. de JESUS, Livro da vida, p. 41.

${ }^{116}$ T. d'ÁVILA, Livro da vida, p. 95. Comparar com a outra edição usada: T. de JESUS, Livro da vida, p. 68. Cf. o estudo de A. CEA GUTIÉRREZ, Modelos para una santa. El icono en la vida de Teresa de Ávila. In: I. ARELLANO e M. VITSE (coords.), Modelos de vida en la Espäna del siglo de Oro, t. II, p. 401-437.

${ }^{117}$ L. ALGRANTI, Livros de devoção, atos de censura, p. 75-92.

${ }^{118}$ T. d'ÁVILA, Livro da vida, p. 105. Comparar com a outra edição usada: T. de JESUS, Livro da vida, p. 76-77.
} 
trasladado pelo confessor Manoel de Jesus, Jacinta se exprimiu da maneira seguinte, a respeito da completude de uma alma em plena união com Deus:

Esta alma assim farta e cheia não Cabe em si. Começa a dar, digo também que nela se acha sempre este receber e dar, digo assim como uma fonte que em contínuo correr sem cessar se acha, quero dizer melhor; e não sei como me explique, digo assim como um vaso na fonte em o qual vaso esta Corre, e nele [sic] está posto para nele ela Correr, e que este já cheio entra a derramar por todos os Lados [...] assim digo, Padre meu, que é uma alma posta nesta fonte. ${ }^{119}$

Em comum, não existe apenas a compreensão da esfera espiritual por meio de metáforas, mas a específica menção à água como analogia para designar a substância divina que impregna as almas mais perfeitas. ${ }^{120}$ Outras semelhanças aparecem nas descriçóes do estado da alma quando se encontra em plena união com Deus. Principalmente no quarto grau de oração, o mais elevado, Santa Teresa assinala a suspensão das potências da alma - entendimento, memória e vontade - de modo a atingir um vazio, que é plenamente preenchido por Deus: "aqui não há sentir, mas apenas fruir, sem entender o que se frui”. E, um pouco mais adiante no Livro da Vida, o Senhor teria lhe dito: "Desfaz-se toda, filha, para pôr-se mais em mim. Já não é ela quem vive, mas sim Eu. Como não pode compreender o que entende, é não entender entendendo". ${ }^{121}$ Em um traslado dos escritos de Jacinta enviados pelo confessor à Inquisição, a beata mística referia que:

É tão divina esta divina vida que é só meu senhor o que nesta vive; não digo isto porque eu também não viva, porém vive só neste estado santo alma [sic]. Como a morte, ou morto, não diz, não sabe, não sente e não se move, aqui a alma está de todo morta, e tão morta que não há o mais pequeno movimento, é um morto sem sentidos, é morto sem potências, e é nada vendo que nada é, nada pode, nada faz, nada, e nestes nadas em que se vê posta, fica toda cheia e farta. Aqui o entendimento é morto, a memória não só é morta, mas também não [ilegível], a vontade é a principal potência que aqui se acabou. ${ }^{122}$

\footnotetext{
${ }^{119}$ ANTT, TSO, IL, processo no 4423, f. 8v-9.

${ }^{120}$ Cf. também T. de JESUS, Castelo interior. In: Obras completas, p. 446, ao se referir às obras de uma alma em estado de graça: "elas procedem dessa fonte da vida na qual, à semelhança de uma árvore, a alma está plantada; e ela não teria frescor nem fertilidade se não estivesse ali, sendo a água responsável pelo seu sustento e pelos seus bons frutos".

${ }^{121}$ T. d'ÁVILA, Livro da vida, p. 159-160 e 165. Comparar com a outra edição usada: T. de JESUS, Livro da vida, p. 113 e 117.

${ }^{122}$ ANTT, TSO, IL, processo no 4423, f. 6v-7.
} 
Em análise a respeito de Rosa de Lima, Frank Graziano indicou a apropriação de leituras religiosas por parte da santa peruana, que as evocava como se tivesse passado pelas mesmas experiências descritas nas narrativas. ${ }^{123}$ É possível que uma situação semelhante tenha se verificado com Jacinta diante dos escritos de Santa Teresa. Em um contexto em que era muito diferente a concepção de autoria, a beata mística desenvolveu diversos temas teresianos, sem indicar as fontes de sua possível inspiração. Certamente não foi a única seguidora da santa de Ávila a agir de tal maneira. Maria Isabel das Chagas, uma beata portuguesa do século XVII, era "tão versada nas obras de santa Teresa que parecia que as tinha aprendido de memória", segundo as autoridades eclesiásticas. ${ }^{124}$ Sem pretensão de exaurir todos os exemplos, outros paralelos podem ser encontrados entre os escritos de Santa Teresa e de sua discípula fluminense: a linguagem do matrimônio místico, ${ }^{125} \mathrm{a}$ "retórica da feminilidade", em que era assinalada a fraqueza e a obediência das místicas diante da autoridade religiosa masculina, com a finalidade estratégica de garantir a legitimidade das visōes; etc. ${ }^{126}$ Deixando os escritos de Santa Teresa e consultando outra obra fundamental da literatura mística do século XVI, o Tratado de Sáo Pedro de Alcântara, percebem-se diversas correspondências entre as meditaçôes da Paixão de Cristo comentadas pelo santo franciscano e um fragmento da crônica de Jacinta. ${ }^{127}$

\footnotetext{
${ }^{123}$ F. GRAZIANO, Wounds of Love, p. 55.

${ }^{124}$ C. M. BORGES, Las hijas de Teresa de Ávila. In: M. I. VIFORCOS MARINAS e R. LORETO LÓPEZ (coords.), Historias compartidas, p. 187.

125 T. de JESUS, Castelo interior, p. 565-570. B. da S. LISBOA, Annaes, p. 427. Fr. N. de SĀO JOSÉ, Vida da serva de Deus, p. 76. L. ALGRANTI, Livros de devoção, atos de censura, p. 116. Ver também a importante análise de A. LAVRIN relativa ao matrimônio místico, cuja linguagem remonta ao Cântico dos Cânticos. Brides of Christ, p. 90-95.

126 T. d'ÁVILA, Livro da vida, p. 69, 102, 111 e 396. ANTT, TSO, IL, processo no 4423, f. 8v, em cujo trecho Jacinta se espantava pelo fato do Senhor ter beneficiado tanto uma "imunda besta ingrata que sou eu e sempre fui".

${ }^{127}$ P. de ALCÂNTARA, Tratado da oração e da meditação, p. 59-84; Fr. N. de SÃO JOSÉ, Vida da serva de Deus, p. 54-56. Apenas um pequeno exemplo: após a Oração do Horto, na terça-feira antes da Paixão, o Senhor afastou-se dos discípulos e, segundo o Tratado, "começou a suar gotas de sangue, que iam por todo o seu sagrado corpo fio a fio até cair em terra" (p. 65). Eis o trecho correspondente da Vida de Jacinta: "quando o Senhor se pôs a orar no Horto das Oliveiras, entendeu a Serva de Deus que a alma santíssima de Jesus ficou inundada de júbilo por ter chegado a hora táo desejada de sacrificar sua vida pela salvaçáo do mundo; mas essa alegria foi logo perturbada pela tristeza mortal que lhe causava o pensamento de que tantas almas se haviam de perder, apesar de sua Paixão e Morte dolorosíssima. Começou então a suar sangue por todas as partes do seu corpo" (p. 55).
} 


\section{Considerações finais}

Após ter percorrido três caminhos, diferentes e complementares, para tornar mais compreensível a vivência religiosa de Jacinta, espera-se ter suprido algumas lacunas das interpretaçóes anteriores. A beata mística emerge em uma moldura mais complexa, onde figuram ordens religiosas em disputa pela sua direção; praticantes do ideal eremítico, que podem tê-la influenciado a se recolher na Chácara da Bica para ali fundar um Recolhimento; o pertencimento a uma das mais opulentas famílias fluminenses, o que tornava mais compreensível o irrestrito apoio que foi mais tarde concedido à Jacinta pelo governador do Rio de Janeiro; a familiaridade com o universo da leitura, sobretudo da literatura mística de Quinhentos; as diferenças entre as práticas de escrita adotadas pelos hagiógrafos e aquelas presentes na documentação inquisitorial; etc. Dando continuidade à análise da trajetória espiritual de Jacinta, espera-se, em uma ocasião oportuna, deslocar o foco para um momento posterior, constituído pelos conflitos mantidos entre e beata mística e o bispo do Rio de Janeiro.

\section{Referências bibliográficas}

\section{Fontes impressas}

ALCÂNTARA, P. de, Santo. Tratado da oração e da meditação (1556). 2. ed. Petrópolis: Vozes, 2008.

ARAÚJO, Mons. J. de S. A. P. de. Memórias históricas do Rio de Janeiro. 2. ed. Rio de Janeiro: Imprensa Nacional, 1946, v. 4.

Convento de Santa Teresa: Notícia histórica pelas religiosas do Convento. Rio de Janeiro, 1955.

D’ÁVILA, T., Santa. Livro da vida (1588). São Paulo: Penguin Classics/Cia. das Letras, 2010.

Fr. A. HAZA. Estatutos de terceros, extraidos e recopilados de la Tercera Orden Serafica, que tercera vez Dio à luz el erudito y Venerable Padre Arbiol [...]. En Vitoria: Por Bartholomè Riesgo y Montero, [...] Anô de 1726.

JESUS, T. de, Santa. Obras completas. Ed. bras. Estabelecida a partir do texto revis. e anot. por fr. Tomas de la Cruz, O. C. D. 3. ed. São Paulo: Loyola, 2008.

LISBOA, B. da S. Annaes do Rio de Janeiro. Rio de Janeiro: Seignot-Plancher, 1835, t. VII.

SANTA MARIA, Fr. A. de, O. S. A. Santuário mariano, e História das Imagens milagrosas de Nossa Senhora. Tomo décimo e último. Lisboa Ocidental, na Oficina de Antonio Pedrozo Galram, Com todas as licenças necessárias, Ano de 1723.

SÃO JOSÉ, Fr. N. de, O. C. D. Vida da serva de Deus madre Jacinta de São José. Rio de Janeiro: Cia. Mendes Jr., 1935.

SOLEDAD, Fr. Domingo de la, O. F. M. Sol Seraphico que colocado em el cenit del Catholico Cielo, ilustra al Christiano Orbe com los beneficos rayos del Origen, Excelencias, Frutos, Regla, e Indulgencias de la estimada deDios, apreciada de los Pontifices, 
y venerada de los Hombres, la siempre Venerable Orden Tercera de Penitenciade N. S. P. S. Francisco [...]. s. e, s/d [2. ed. Cádiz: Jeronimo de Peralta, 1728].

\section{Estudos}

ALGRANTI, L. M. Honradas e devotas: mulheres da Colônia. Condição feminina nos conventos e recolhimentos do sudeste do Brasil, 1750-1822. Rio de Janeiro: José Olympio; Brasília: Ed. UnB, 1993.

ALGRANTI, L. M. Livros de devoção, atos de censura: ensaios de história do livro e da leitura na América Portuguesa (1750-1821). São Paulo: Hucitec: Fapesp, 2004.

ALMEIDA, S. C. C. O sexo devoto: normatização e resistência feminina no Império português, XVI-XVIII. Recife: Ed. Universitária UFPE, 2005.

AZZI, R. e REZENDE, M. V. A vida religiosa feminina no Brasil colonial. In: R. AZZI (org.). A vida religiosa no Brasil: enfoques históricos. São Paulo: Paulinas, 1983, p. 24-60.

BATAILLON, M. Erasmo y España: estudios sobre la historia espiritual del siglo XVI. 2. ed. México: Fondo de Cultura Económica, 1996.

BORGES, C. M. M. A conquista do espaço público: o protagonismo feminino nos séculos XVII e XVIII na esfera religiosa. In: C. SARMENTO (Coord.).Condição feminina no Império colonial português. Porto: Instituto Politécnico, 2008, p. 265-273.

BORGES, C. M. M. As mensageiras do Senhor: a situação ambígua das beatas na Península Ibérica - séculos XVI a XVIII. In: A. A. F. de ASSIS e M. S. PEREIRA (orgs.), Religióes e religiosidades: entre a tradição e a modernidade. São Paulo: Paulinas, 2010, p. 15-27.

BORGES, C. M. M. Las hijas de Teresa de Ávila: espiritualidad mística entre mujeres de la península ibérica y del Brasil colonial. In: M. I. VIFORCOS MARINAS y R. LORETO LÓPEZ (coords.). Historias compartidas: religiosidad y reclusión femenina en España, Portugal y América. Siglos XV-XIX. León: Universidad de León; Puebla: Benemérita Universidad Autónoma de Puebla, 2007, p. 177-193.

BOSCHI, C. C. Ordens religiosas, clero regular e missionação no Brasil. In: F. BETHENCOURT e K. CHAUDURI (dir.). História da expansão portuguesa. Lisboa: Círculo de Leitores, 1998, v. 3, p. 294-318.

BOURDIEU, P. Gênese e estrutura do campo religioso. In: A economia das trocas simbólicas. 2. ed. São Paulo: Perspectiva, 1987, p. 27-98.

BOXER, C. R. A Igreja e a expansão ibérica (1440-1770). Lisboa: Ed. 70, 1981.

CALDERÓN, V. Biografia de um monumento: o antigo Convento de Santa Teresa da Bahia. Salvador: Ed. Beneditina, 1971.

CEA GUTIÉRREZ, A. Modelos para una santa. El icono en la vida de Teresa de Ávila. In: I. ARELLANO y M. VITSE (coords.). Modelos de vida en la España del siglo de Oro. Madrid: Iberoamericana, 2007. t. II, p. 401-437.

DIAS, J. S. da S. Correntes de sentimento religioso em Portugal(séculos XVI a XVIII). Coimbra: Instituto de Estudos Filosóficos da Universidade de Coimbra, 1960. t. 1.

FERNANDES, M. L. C. Introdução. In: Fr. L. dos ANJOS, O.F.M. Jardim de Portugal (1626). Porto: Campo de Letras, 1999. p. 9-29.

PALAZOLLO, Fr. J. de, O. F. M. Cap. Crônica dos capuchinhos do Rio de Janeiro. Petrópolis: Vozes, 1966. 
FRANCO JR., H. F. Apresentação. In: J. de VARAZZE. Legenda Áurea: vidas de santos. São Paulo: Cia. das Letras, 2006. p. 11-25.

FRANCO, J. Plotting Women: Gender and Representation in Mexico. New York: Columbia University Press, 1989.

GONÇALVES, M. de A. Império da fé: andarilhas da alma na época barroca. Rio de Janeiro: Rocco, 2005.

GRAZIANO, F. Wounds of Love: The Mystical Marriage of Saint Rose of Lima. Oxford: Oxford University Press, 2004.

IRIARTE, Fr. L., O. F. M. Cap. História Franciscana. Petrópolis: Vozes, 1985.

KESSEL, E. Virgens e mães entre o céu e a terra. In: A. FARGE \& N. Z. DAVIS (dir.). Do Renascimento à Idade Moderna (História das mulheres no Ocidente, v. 3). Lisboa: Afrontamento, 1994, p. 180-227.

KING, M. A mulher do Renascimento. Lisboa: Presença, 1994.

LAVEN, M. Virgens de Veneza: vidas enclausuradas e quebra de votos no convento renascentista. Rio de Janeiro: Imago, 2003.

LAVRIN, A. Brides of Christ: Conventual Life in Colonial Mexico. Stanford: Stanford University Press, 2008.

LE GOFF, J. O nascimento do Purgatório. Lisboa: Estampa, 1993.

LEITE, S. J. História da Companhia de Jesus no Brasil. Rio de Janeiro: INL; Lisboa: Portugália, 1945. t. VI.

MARTINA, G. A era do absolutismo. (História da Igreja, de Lutero a nossos dias, v. 2). 2. ed. São Paulo: Loyola, 1996.

MARTINS, W. de S. Membros do corpo mistico: ordens terceiras no Rio de Janeiro (c. 1700 - 1822). São Paulo: Edusp, 2009.

MARTINS, W. de S. D. Domingos do Loreto Couto e a construçáo de modelos de santidade feminina na época colonial. In: Revista do Mestrado de História, 11, 1 (2009): 193-229.

MAURÍCIO, A. Igrejas históricas do Rio de Janeiro. Rio de Janeiro: Kosmos: Secretaria Estadual de Educação e Cultura, s/d.

MYERS, K. A. Redeemer of America: Rosa de Lima (1586-1617), the Dynamics of Identity, and Canonization. In: A. GREER e J. BILINKOFF (eds.). Colonial Saints: Discovering the Holy in Americas, 1500-1800. New York: Routledge, 2003. p. 251-275.

NEMBRO, Fr. M. da, O. F. M. Cap. Storia dell'attivitá missionária dei minori cappuccini nel Brasile (1538? - 1889). Rommae: Institutum Historicum Ord. Fr. Min. Cap., 1958.

PAZ, O. Sóror Juana Inés de la Cruz: as armadilhas da fé. 2. ed. São Paulo: Mandarim, 1998.

PIRES, L. G., Para uma leitura intertextual de "Exercícios espirituais" do padre Manuel Bernardes. Lisboa: INIC: Centro de Literaturas de Expressão Portuguesa da Universidade de Lisboa, 1980.

PRIMERIO, Fr. F. Capuchinhos em Terras de Santa Cruz nos séculos XVII, XVIII e XIX. São Paulo: Martins, 1942.

REZENDE, Fr. M. e PRIMERIO, Fr. F., O. F. M. Cap. Os missionários capuchinhos no Brasil: esboço histórico. São Paulo: Convento da Imaculada Conceição, 1929. 
RHEINGANTZ, Primeiras famílias do Rio de Janeiro(séculos XVI e XVII). Rio de Janeiro: Brasiliana, 1965-1967, $2 \mathrm{v}$.

RUBERT, Pe. A. Historia de la Iglesia en Brasil. Madrid: Mapfre, 1992.

RUBIAL GARCIA, A. Profetisas y solitários: espacios y mesajes de una religión dirigida por ermitãnos y beatas laicos en las ciudades de Nueva España. México: UNAM: Fondo de Cultura Económica, 2006.

SÁNCHEZ LORA, J. L. Mujeres, conventos y formas de la religiosidad barroca. Madrid: Fundación Universitaria Española, 1988.

SILVA, M. B. N. da. Ser nobre na Colônia. São Paulo: Unesp, 2005.

SILVA, M. B. N. da. Sistema de casamento no Brasil colonial. São Paulo: T. A. Queiroz: Edusp, 1984.

SOEIRO, S. The Feminine Orders in Colonial Bahia, Brazil. In: A. LAVRIN, Latin American Women: Historical Perspectives. Westport: Greenwood Press, 1978. p. 173-197.

SOUZA, L. M. de. Inferno Atlântico: demonologia e colonização, séculos XVI - XVIII. São Paulo: Cia. das Letras, 1993.

TAVARES, P. V. B. Caminhos e invençôes de santidade feminina em Portugal nos séculos XVII e XVIII (alguns dados, problemas e sugestôes). In: Via Spiritus, 3, (1996): 163-215. TUDELA, E. S. V. Colonial Angels: Narratives of Gender and Spirituality in Mexico, 1580 - 1750. Austin: University of Texas Press, 2000.

VAUCHEZ, A. A espiritualidade na Idade média ocidental (séculos VIII a XIII). Rio de Janeiro: Jorge Zahar, 1995.

VOLLENDORF, L. Transatlantic Ties: Women's Writing in Iberia and the Americas. In: D. KOSTROUN \& L. VOLLENDORF. Women, Religion and Atlantic World (16001800). Los Angeles: UCLA Center for 17th-18th Centuries Studies, 2008, p. 79-112. WEBER, A. Little Women: Counter-Reformation Misogyny. In: D. M. LUEBKE (ed.). The Counter Reformation: The Essential Readings. Malden: Blackwell Publishing, 2005. p. 144-161.

Recebido: 18/01/2012

Aprovado: 11/03/2012 